\title{
Excess control rights and corporate acquisitions
}

\author{
François Belot • \\ This version: November 2010
}

\begin{abstract}
The typical French listed company exhibits a concentrated ownership structure with the largest shareholder typically holding more voting rights than cash flow rights. This paper studies the acquisitions made by French listed firms over the period 2000 through 2009 and investigates how such ownership characteristics affect acquirer abnormal returns and acquisition activity. Abnormal returns around acquisitions are decreasing as the wedge between voting and cash flow rights increases. This result suggests that controlling shareholders use corporate acquisitions as a means of extracting private benefits at the expense of minority shareholders. The well-documented valuation discount associated with the divergence between voting and cash flow rights could be explained by less efficient acquisitions. The paper also shows that firms whose largest shareholder holds significant excess control rights are less likely to engage in M\&A activity. This last finding raises the issue of sample selection bias, which has not been taken into account in earlier studies.
\end{abstract}

Keywords: ownership structure, excess control rights, corporate acquisitions, acquirer returns, bidding likelihood

JEL Classification: G32, G34

\footnotetext{
- PhD candidate,

Université Paris-Dauphine, DRM. Place du Maréchal de Lattre de Tassigny, 75775 - Paris cedex 16.

Tel : + 33144054227 - Fax : + 33144054023

Email : francois.belot@dauphine.fr

This paper is part of a doctoral research conducted under the supervision of Prof. Edith Ginglinger.

I thank Edith Ginglinger and John Lewis for insightful comments.
} 


\section{Introduction}

Ownership structure acts as an internal governance mechanism. Large shareholders are likely to play an important role in exercising corporate governance as their ownership stakes provide them with the incentives to collect information, scrutinize manager actions and oppose value-destroying decisions (Shleifer and Vishny, 1997; Denis and McConnell, 2003). Recent studies emphasize the prevalence of concentrated ownership structures around the world, this being especially true for East Asia (Claessens et al., 2000) or Continental Europe (Faccio and Lang, 2002) but also in the United States, despite the conventional wisdom suggesting that the typical U.S. public firm has diffuse ownership (Holderness, 2009). Although being associated with numerous advantages (all shareholders will benefit from the monitoring effort made by a large blockholder), concentrated ownership might generate severe agency costs. A controlling shareholder has the power to influence corporate decisions and is in a position to enjoy private benefits which, by definition, are not shared with other (minority) shareholders. These private benefits can take numerous forms: tunneling of resources out of firms (Johnson et al., 2000), nepotism or the prestige and social status derived from the control of a well-known company. ${ }^{1}$

When making a corporate decision, the controlling shareholder faces a trade-off between (1) private benefits she will solely enjoy and (2) the change in her net wealth induced by the evolution of firm value. For instance, the controlling shareholder is likely to give consent to an investment with negative present value if the benefits she derives outweigh the incurred loss induced by the stock price decrease.

As emphasized by Bebchuk et al. (2000) and Morck et al. (2005), agency conflicts between large and minority shareholders are magnified when the largest shareholder owns control (i.e. voting) rights which strongly exceed her fraction of the equity claims on a company cash flows. Such a separation of ownership and control can be realized through control enhancing mechanisms like pyramids, dual-class shares and cross-holding ties. The above mentioned studies demonstrate that controlling owners often lock control over their companies through these control enhancing mechanisms. Of all the 464 European companies

\footnotetext{
${ }^{1}$ There is no precise definition of the true nature of private benefits of control. Jensen and Meckling (1976, p. 312) evoke the benefits associated with the owner-manager status: "[...] pecuniary returns but also the utility generated by various non-pecuniary aspects of his entrepreneurial activities such as the physical appointments of the office, the attractiveness of the office staff, the level of employee discipline, the kind and amount of charitable contributions, personal relations ("friendship," "respect," and so on) with employees, a larger than optimal computer to play with, or purchase of production inputs from friends".
} 
analyzed in a study commissioned by the European commission, $44 \%$ feature at least one control enhancing mechanism (ISS, Sherman and Sterling, ECGI, 2007).

This raises the question of the costs and subsequent loss of social welfare associated with a separation of ownership from control. Claessens et al. (2002) and Lins (2003) empirically demonstrate that firm valuation is lower when the control rights of the largest owner strongly diverge from her cash-flow rights. Confirming these results, Guedhami and Misra (2009) show that equity financing is more expensive for firms whose controlling shareholder holds excess control rights. These studies support the agency hypothesis that large shareholders extract private benefits at the expense of minority shareholders. However, an important question is (partially) left unanswered in earlier studies: what exactly are the channels through which such extraction occurs? In other words, what are the corporate decisions that a controlling shareholder influences in order to advance her own interests?

In this paper, the focus is on corporate acquisitions. They have long been recognized as crucial events that are potentially associated with the consumption of perks or private benefits. Owner-managers may be prone to invest excess cash-flows in corporate acquisitions that maximize their own utility rather than firm value (Jensen, 1986) and entrench themselves (Shleifer and Vishny, 1989). The consequences of (bad) corporate acquisitions are of significant economic importance: Moeller at al. (2005) demonstrate that, over the period 1998 through 2001, acquiring-firm shareholders lost around announcement 12 cents per dollar spent on acquisition. To the extent that acquisitions of other companies are among the most important decisions a firm has to make, one could expect conflicts between controlling and minority shareholders to be extremely severe during acquisition periods.

The link between ownership structure and corporate acquisitions has received some attention in financial literature. Ben-Amar and André (2006) study a sample of Canadian bidders and observe a non linear relationship between the largest shareholder stake and announcement-period abnormal returns; howewer they do not find that separation of ownership and control has a negative impact. The distinctive feature of my paper is its focus on France, a country whose institutional framework and ownership characteristics strongly differ from those analyzed in earlier studies. French firms typically have a concentrated ownership and a controlling shareholder who holds control rights which exceed her cash-flow rights. In the majority of the cases, this high discrepancy comes from the typical French system of double voting rights (Burkart and Lee, 2008). Furthermore, the protection of minority investors under French law is weak (La Porta et al., 1998). Thus, there is scope for severe conflicts between large and minority shareholders. 
To carry out my analysis, I collected relevant data pertaining to ownership structure for SBF250 firms. ${ }^{2}$ Due to changes in the composition of this index, my initial sample contains 400 unique firms. I then construct a sample of 660 acquisitions that were announced by these firms over the decade from 2000 to 2009. An important characteristic of this paper is that it relies (1) on an acquisition sample (that is to say a sample of firms which actually announce an acquisition) and (2) on a larger sample of listed companies, with only some participating in the M\&A market as bidders. The 660 acquisitions were in fact initiated by 196 companies, which demonstrate that approximately one half of SBF250 companies did not announce a takeover bid over a 10-year period. In contrast to earlier studies, my methodology allows me to control for a potential selection bias that derives from the fact that the choice of bidding is not random.

I observe a negative and significant relationship between excess control rights and abnormal returns around acquisition announcements. This result shows that acquisitions initiated by firms whose largest shareholder holds excess control rights are detrimental to firm value and suggests that corporate acquisitions are a means of private benefits extraction at the expense of minority shareholders. I also investigate whether other large shareholders play a monitoring role. These blockholders are associated with higher value losses and thus do not appear as credible safeguards. Interestingly, further empirical tests do not validate the hypothesis of collusion between these blockholders and the largest one.

In a second line of analysis, I examine the acquisition behavior of French listed companies. It clearly appears that entrenched owners are very cautious toward acquisitions. One possible explanation is that they fear the dilution of their power that could be induced by a stock-financed deal. My acquisition sample is hence biased toward firms with a lower separation of ownership and control. After controlling for sample selection bias, the main findings hold.

Finally, I try to control for endogeneity issues that inevitably arise in corporate governance studies dedicated to the ownership - performance relationship (Demsetz and Lehn, 1985). I use the instrumental variables technique, which leads me to propose different variables that can influence the separation of ownership and control without directly influencing the performance measured by announcement-period abnormal returns. I discuss the relevance of this methodology which confirms previous findings.

\footnotetext{
${ }^{2}$ The SBF250 index is composed of the 250 firms with the largest market capitalizations on the Paris Stock Exchange.
} 
This paper is related to the literature that seeks to understand why excess control is associated with a valuation discount. Masulis et al. (2009) examine a sample of U.S. dualclass companies and show that abnormal returns around acquisition announcements are decreasing as the insider control rights - cash flow rights divergence becomes larger. As suggested by these authors, further international inquiry is needed in order to extend understanding of private benefits extraction through other control enhancing mechanisms that are not (or rarely) encountered in the United States. This paper fills that gap by showing that voting arrangements at the company level significantly harm firm performance. Furthermore, there is no evidence of lower abnormal returns for acquisitions announced by firms controlled via pyramid structures, which is consistent with empirical studies (Villalonga and Amit, 2009) and theoretical models (Almeida and Wolfenzon, 2006; Riyanto and Toolsema, 2008) that provide rationale for pyramidal ownership.

The remainder of the paper is organized as follows. Section 2 describes the French framework and reviews the literature dedicated to the relationship between ownership and acquisitions. Section 3 deals with the methodology, the sample selection and the construction of variables that are likely to play a role in explaining acquisition quality and why some firms engage in acquisitions. Section 4 presents the results of the empirical analysis. Section 5 reports results from robustness checks aimed at testing whether results are still valid on subsamples, correcting selection bias and controlling for endogeneity. Section 6 concludes.

\section{Background}

\subsection{The French case}

A recent study commissioned by the European commission (ISS, Sherman and Sterling, ECGI, 2007) describes the availability of control enhancing mechanisms in Europe. In every country, external mechanisms (pyramids and cross-shareholdings) are encountered. In France, multiple voting shares (in a special form, see below), non-voting shares and non-voting preference shares can be observed. From the sample of French civil law countries (La Porta et al., 1998), France is the only one in which these three mechanisms are authorized.

In the vast majority of French listed companies, the deviation from the one share-one vote principle is realized through double voting rights shares (Burkart and Lee, 2008). The charter of the firm can authorize double voting rights for registered shares that have been held for a 
defined number of years (between 2 and 4 years). Officially, such double voting rights are aimed at rewarding long-term shareholders. It should be noted that these double voting rights are very different from dual-class shares frequently adopted by American and Swedish companies. ${ }^{3}$ The double voting right "belongs" to a registered long-term shareholder but is lost as soon as the share is sold to another party. Shares must be held during the specified period (for instance 2 years) before obtaining an extra voting right. Contrary to dual-class shares, there is only one market price for single and double-voting shares. This mechanism has not been taken into account in Faccio and Lang's (2002) study, hence their ownership data tend to underestimate the wedge between ownership and control in their sample of French listed companies. However, the use of this control device is far from anecdotal: Ginglinger and Hamon (2009) report that the double voting mechanism is in force in $68.3 \%$ of French companies.

Dual-class structures are rarely observed in French listed companies. As in Italy (see Zingales, 1994), the only authorized mechanism consists of non-voting shares (which cannot account for more than $25 \%$ of existing equities).

My focus on French companies is also motivated by the specificities of the legal and institutional framework. Johnson et al. (2000) document anecdotal evidence of tunneling in a French firm. In an attempt to assess the size of private benefits of control, Nenova (2003) considers that controlling shareholders appropriate $27 \%$ of the value of the company in France. La Porta et al. (1998) compute the "antidirector rights index" which is equal to 5 for the USA and only 3 for France; Djankov et al. (2008) develop the "anti self-dealing index" whose value is 0.65 for the USA and 0.38 for France. From these measures, the level of protection afforded to investors in France seems to be weak. As ownership concentration and legal investor protection are often viewed as substitutes (see for instance Denis and McConnel, 2003), the high ownership concentration observed in French firms is not surprising (only 14\% of French listed companies are widely held at the $20 \%$ threshold according to Faccio and Lang, 2002). In this context, Boubaker (2007) find results that are consistent with those observed in earlier studies: a high separation of ownership and control is associated with lower firm value.

Some authors argue that extralegal institutions may discourage predatory behavior by controlling shareholders. Dyck and Zingales (2004) claim that product market competition,

\footnotetext{
${ }^{3}$ According to Rydqvist (1996) and Cronqvist and Nilsson (2003), dual-class structures are encountered in approximately $75 \%$ of Swedish listed companies. Gompers et al. (2010) show that approximately $8 \%$ of the firms covered by Compustat exhibit a dual-class structure.
} 
public opinion pressure, moral norms, unions and tax enforcement may play an important role in curbing private benefits. The question of whether France offers such extra-legal institutions arises. Dyck and Zingales (2004) propose six different numerical proxies aimed at capturing the quality of extra-legal institutions and France is on the average. Stulz and Williamson (2003) consider that religion is a good proxy for cultural norms and show that religions are associated with significant differences in shareholders rights. In particular, Catholic countries (as France) protect the rights of creditors less well.

In sum, France is characterized by weak corporate governance at the firm level and by a legal and institutional framework which does not offer strong protection against minority expropriation. Extra-legal institutions do not appear as a credible counterforce. Consequently, the conflict of interests between controlling and minority shareholders may be extremely severe in French listed companies and there may be scope for private benefits extraction through different channels. This paper tests whether corporate acquisitions are one of them.

\subsection{Ownership-control discrepancy and acquirer returns}

The conflict of interests between dominant and minority shareholders may be extremely severe during acquisitions as the former may use the transaction as a channel of private benefit extraction at the expense of the latter. Some papers focus on intra-group transactions and hence test the tunneling hypothesis. According to this hypothesis, it may be beneficial for the ultimate owner of a pyramidal business group to favor intragroup transactions so as to transfer wealth to the upper level at the expense of minority shareholders at lower levels. Studying a sample of Indian companies, Bertrand et al. (2002) document evidence of tunneling. In the Korean framework, Bae et al. (2002) show that an acquisition made by a chaebol-affiliated firm is value-destroying but that the controlling shareholder benefits from it as an increase of the stock prices of other firms in the business group is observed. However, Buysschaert et al. (2004) and Faccio and Stolin (2006) examine European transactions and do not find any evidence of disproportional sharing of the gains between controlling and minority shareholders. Their results cast doubt on the existence of resources diversion through corporate acquisitions. In another European study focused on the Swedish case, Holmen and Knopf (2004) examine a sample of 121 mergers occurring over the years 1985 to 1991. They do not document any flagrant expropriation of minority shareholders through deals involving companies both controlled by a common shareholder. 
Recent papers tackle the issue of the relationship between ownership structure and quality of the acquisition as measured by abnormal returns around the announcement date. Bigelli and Mengoli (2004) construct a sample of 228 acquisitions made by Italian listed companies over the years 1989 to 1996 . This sample is well suited as (1) a large number of Italian companies exhibit a dual-class structure and (2) acquisitions were realized before the adoption of a major corporate governance reform which strongly reinforced the rights of minority shareholders. ${ }^{4}$ The authors show that cumulative abnormal returns are increasing in the ratio of cash-flow rights over voting rights held by the largest shareholders. In other words, the quality of the acquisitions is lower when there is a high separation of ownership from control. This result tends to validate the hypothesis of private benefits extraction through corporate acquisitions. Using a sample of 410 mergers and acquisitions made by U.S. dual-class companies, Masulis et al. (2009) demonstrate that the excess-control rights of the dominant owner negatively affect the acquirer returns. This result confirms that the separation of ownership and control is an important issue even in countries considered as protective of shareholder rights. However, Ben-Amar and André (2006) examine a sample of 327 acquisitions made by 232 Canadian firms and do not find that separation of ownership and control has a negative impact on performance.

This brief review of the literature shows that there is no clear relationship between separation of ownership and control and acquisitions' quality. This paper contributes to this debate and provides new evidence from the French case.

\subsection{Propensity to engage in acquisitions}

Financial literature emphasizes the fact that managers can use corporate acquisitions as means of implementing their own agendas (empire building strategies). Large shareholders have strong incentives to scrutinize manager actions and are thus likely to prevent such opportunistic behaviors. Burkart et al. (1997) develop a model in which this tight monitoring can deter management initiatives and discourage the manager from searching for investment projects. Consequently, a negative association between the largest shareholder's stake and the likelihood of becoming a bidder is expected. Such a relationship is empirically observed by Amihud and Lev (1981): the average number of acquisitions is higher for manager-controlled than for owner-controlled companies.

\footnotetext{
${ }^{4}$ Dyck and Zingales (2004) indeed observe that the amount of private benefits dramatically dropped after the adoption of this reform (also known as the Draghi reform).
} 
The sense of the relationship between ownership/control discrepancy and bidding likelihood is not an obvious issue. A high difference between cash-flow rights and votingrights is likely to induce suboptimal behavior of the controlling owner who has fewer incentives to exercise tight control over the manager's decisions. A positive association between the ownership-control discrepancy and the number of acquisitions can hence be expected.

Moreover, large shareholders have a significant part of their wealth concentrated in their own companies and suffer from high exposure to firm-specific risk. Diversifying acquisitions can be viewed as means by which ultimate owners reduce the risks associated with firm-specific investments (Amihud and Lev, 1981). Claessens et al. (1999) show that a larger divergence between control and cash-flow rights is associated with more corporate diversification; they conclude that large shareholders use diversification to extract private benefits at the expense of minority shareholders. One could hence expect that the propensity to engage in acquisitions increases in the amount of the wedge between voting and cash-flow rights. This hypothesis is empirically validated by Faccio and Masulis (2005) who notice that firms whose largest shareholder holds voting rights in excess of her cash-flow rights are more likely to launch takeovers. 5

However, some theories suggest an opposite relationship. Acquisitions are associated with a potential loss of control. A stock payment implies a dilution of the largest owner's voting power and the emergence of an outside blockholder if the target is not a widely held company. There is also an indirect dilution threat for cash-financed deals: the funding of a cash takeover through debt increases bankruptcy risk and thus the probability of future equity issuances aimed at refinancing this debt. Additionally, Martynova and Renneboog (2009) point out the fact that transactions classified as all cash-offers in fact often imply equity financing. Accessing such an equity financing may be especially difficult for a firm whose controlling shareholder hold voting rights in excess of her cash flow rights: investors anticipating future expropriation can be reluctant to buy company's newly issued shares.

An important private benefit that is derived from the control of a corporation is the ability to allot significant management positions or board seats to friends (nepotism). This issue is especially relevant for family controlled firms. By selecting the CEO from the small pool of family heirs, the firm might have a top executive who lacks managerial talent. Consistent with this view, Pérez-González (2006) and Bennedsen et al. (2007) find evidence of lower

\footnotetext{
${ }^{5}$ It should be noted that this result is not valid for the sample of European continental bidders (French companies represent $19.8 \%$ of this sample) as the authors observe an insignificant relationship.
} 
operating performance of firms which experienced a family succession. The success of large acquisitions strongly depends on the managerial skills of those who conduct them, for instance highly-skilled CEOs may have abilities to detect good targets. Lacking sufficient skills, heirs CEOs may be less likely to engage in complex acquisitions. In line with this argument, Sraer and Thesmar (2007) show that descendant-managed family firms make significantly fewer acquisitions.

Assuming that a high separation of ownership and control is aimed at protecting the private benefits of the largest owner, these arguments suggest a negative association between excess control rights and the propensity to engage in acquisitions. Studying a sample of 777 European companies, Caprio et al. (2010) validate this hypothesis.

To sum up, the financial literature provides us with mixed and opposite conclusions concerning the sense of the relationship between the ownership/control separation and the propensity to engage in acquisitions. This paper brings new insights about this controversial issue.

\section{Methodology, sample, and variables}

\subsection{Ownership structure analysis}

There is no reliable commercial database dedicated to ownership structures for French listed companies. Consequently, I choose to hand collect the data. The main data sources are the Documents de Reference which can be downloaded from the AMF - the French equivalent of the Securities and Exchange Comission - website (www.amf-france.org). ${ }^{6}$ In some situations, it was necessary to gather information directly from the company's website. In order to properly measure the discrepancy between ownership and control, I use the ultimate ownership methodology developed by La Porta et al. (1999) and frequently adopted in subsequent studies (Claessens et al., 2000; Villalonga and Amit, 2009; among others). I compute the ownership variables at the 10\% threshold. Following Faccio and Lang (2002), ultimate voting-rights are defined as the weakest link along the control chain. Appendix A illustrates the use of this methodology for GROUPE CASINO, an important French food retailer.

\footnotetext{
${ }^{6}$ This document is similar to an annual report but contains detailed information such as the bylaws of the company, an accurate description of the ownership structure and its evolution over the past 3 years.
} 


\subsection{Sample of French listed companies}

I start with the whole sample of French listed companies that are quoted as components of the SBF250 index over the years 2000 to 2008 (415 firms). 15 are excluded, due to missing information about ownership structures. SBF250 components represent, on average, $92.5 \%$ of the whole French market capitalization over the sample period. It is worth mentioning that my panel is an unbalanced one to the extent that some firms enter into the sample (due to IPOs for instance) or exit from it (due to delistings or takeovers). Accounting data are from the Worldscope database. I exclude observations with irrelevant or extreme values. ${ }^{7}$ It should be noted that these exclusions do not change the results.

My sample of acquisitions (see below) encompasses deals made over the period January 2000 through December 2009. As acquisitions in year $t+1$ are matched with ownership structures at the end of year t, I need to collect ownership variables for the years 1999 to 2008. I use a database that was built for another paper (see Belot, 2010) and extend it. However, I do not have the data for the year 1999. I consider that ownership data for the year 2000 are a good proxy for those of the year $1999 .{ }^{8}$ This approximation is relevant if ownership structures are very stable over time as postulated by La Porta et al. (1999); nevertheless some authors argue that a substantial fraction of listed companies exhibit large ownership structure changes over a given year (Denis and Sarin, 1999). I test the hypothesis of the stability of ownership structure by comparing different ownership variables for the years 2001 and 2000. For firms that are continuously traded over these two years, I observe an insignificant decrease in the ultimate cash-flow rights of the largest owner equal to $0.15 \%$ (from $36.17 \%$ in 2000 to $36.02 \%$ in 2001). The hypothesis of stable ownership thus seems to be acceptable; however it could easily be criticized. As a robustness check, I repeat my empirical analysis by excluding the firms whose 1999 ownership variables are proxied by their value in 2000. This does not change the results.

The following table summarizes the construction of the database.

\footnotetext{
${ }^{7}$ Tobin's Q and asset growth are winsorized at 0.999 . I also exclude observations with financial leverage higher than 1. Following Faccio and Masulis (2005), I exclude observations with values of M\&A ACTIVITY (see below) higher than 1 .

${ }^{8}$ It should be noted that ownership variables for 1999 have been manually collected for the firms which make an acquisition in 2000 .
} 


\begin{tabular}{lr}
\hline \hline Number of unique firms (quoted as component of the SBF250 index) & 400 \\
$\Rightarrow$ Potential number of firm-years (10 years from 1999 to 2008) & 4,000 \\
Number of excluded observations (delisting...) & -805 \\
Observations with unavailable accounting/financial data & -56 \\
Observations with unavailable ownership data & -61 \\
Exclusion of outliers & -15 \\
\hline Final number of observations & 3,063 \\
\hline \hline
\end{tabular}

\subsection{Acquisition data}

This paper investigates the likelihood that a given firm announces an acquisition. Therefore, I match the database presented above with the SDC database. I extract all the deals which meet the following criteria:

- The announcement date is between January 1, 2000 and December 31, 2009.

- The acquirer is a French listed company

- The deal value reported in the SDC database is 5 million Euros or higher. This methodological choice leads to the exclusion of trivial operations.

- The bidder is seeking to acquire at least $25 \%$ of the target's shares

- The acquiring company owns less than 50\% of the target's shares prior to the announcement and seeks to own more than $50 \%$ after the transaction. Hence, the focus is on deals that imply a real change of control.

The SDC database reports 821 deals which meet these criteria. I exclude deals initiated by firms which are not in the SBF250 Index (128), I then exclude 5 deals because bidder's financial statements for the fiscal year end preceding the announcement are not available in Worldscope. Market and share price returns are extracted from Datastream. As part of this paper relies on the event-study methodology, a minimum of 210 listing days before the announcement date is needed. Some observations must be excluded, due to an IPO which is too close to the announcement ( 28 observations). At the end, the final sample contains 660 observations.

No restriction is imposed on the bid's outcome. One could argue that deals referred as "completed" are more likely to be associated with higher announcement-period abnormal returns, which could lead to a selection bias. I hence choose to include completed but also 
unsuccessful and withdrawn deals in my sample (in line with Faccio and Masulis, 2005). As a robustness check (see below), I replicate the empirical analysis on the sample of completed deal. This does not change the results.

\subsection{Variables}

\subsubsection{Dependant variables}

In order to capture the bidder announcement effect, I use the classical event-study methodology developed by Ball and Brown (1968) and discussed by Brown and Warner (1980). The announcement effect is measured by the market model adjusted stock return around the announcement date. Following Masulis et al. (2007), the market model parameters are estimated over the 200-day period from event day -210 to event day -11 . The SBF250 index is used in order to compute daily market returns. I calculate cumulative abnormal returns (CARs) over the 3-days period [a-1, a+1] where a is the announcement date as reported in the SDC database.

In the empirical analysis dedicated to the propensity to engage in acquisitions, the dependant variable $y_{i t}$ (with $i$ indicating the company and the year) takes the value of one whether the firm launches a bid in year $t+1$ and 0 otherwise. The total value of deals announced in year $\mathrm{t}+1$ divided by firm's market capitalization at the end of year $\mathrm{t}$ is another metric taken into account.

\subsubsection{Predictor variables: ownership characteristics}

In order to capture the incentive effect induced by a large ownership stake, the ultimate cash-flow rights (S1 UCF) of the largest owner are included. Some authors (Morck et al., 1988; McConnell and Servaes, 1990 among others) argue that the relationship between this latter variable and firm performance is non linear which leads me to include a squared term (S1 UCF^2). In studies dedicated to corporate acquisitions, a non monotonic relationship is observed by Hubbard and Palia (1995) who notice that announcement-period abnormal returns are first increasing and then decreasing in insider ownership.

In order to measure the separation of ownership and control, I use two different measures: the first one (WEDGE) is computed as a difference, the second one (WEDGE RATIO) is measured as the ratio of ultimate cash-flow rights over ultimate voting rights. These two measures are employed by Claessens et al. (2002) and Ben-Amar and André (2006) 
respectively. It should be mentioned that the expected signs of the coefficients are different: if the entrenchment hypothesis is true, a negative (positive) association between WEDGE (WEDGE RATIO) and acquisition announcement CARs is expected. I compute a dummy variable (HIGH WEDGE) which takes the value of one when the variable WEDGE RATIO is inferior to its median value. Thus, this variable takes the value of one when the separation of ownership and control is high.

An historical pattern of French capitalism is the prevalence of family ownership (Murphy, 2005). As previous studies demonstrate that family firms are superior performers (Anderson and Reeb, 2003) and especially better acquirers (Ben-Amar and André, 2006), I control for the identity of the controlling shareholder and create a dummy variable (FAMILY) which takes the value of one whether the ultimate owner of the company (at the 10\% threshold) is an individual or a family.

Laeven and Levine (2008) show that more than one third of Western European companies have a second large shareholder. Bloch and Hege (2001) theoretically demonstrate that the second shareholder is more likely to provide a monitoring effort when she owns cash-flow rights that are close to those of the first shareholder. This proposition is empirically validated by Maury and Pajuste (2005). I hence take into account the existence of other shareholders with different variables: S2 UVR measures the ultimate voting rights of the second large shareholder (if she owns at least $10 \%$ of the voting rights) while S234 UVR is computed as the sum of ultimate voting rights of all shareholders holding at least $10 \%$ of the voting rights. ${ }^{9}$ The aggregate voting rights of all shareholder (except the largest one) owning at least 5\% of the voting rights (OTHERS) are also calculated. Ben-Amar and André (2006) validate the monitoring hypothesis by observing a positive relation between this variable and acquirer returns. However, Maury (2006) finds an overall insignificance of the presence of multiple blockholders.

\subsubsection{Analysis of bidder abnormal returns: control variables}

The industry relatedness of the deal is stored in a dummy variable (DIVER) which takes the value of one when the bidder and the target do not have the same 2-digit SIC code. Morck et al. (1990) observe lower returns for bidders which launch diversifying acquisitions.

\footnotetext{
${ }^{9}$ In my sample, the maximum number of large shareholders (i.e. holding at least $10 \%$ of the voting rights of a given company) is equal to 4 .
} 
I also control for cross-border transactions with a dummy variable (CROSS-BORDER) which is equal to one whether target's and bidder's nations differ. Using a sample of acquisitions made by US firms, Moeller and Schlingemann (2005) demonstrate that bidder announcement returns are lower for non domestic than for domestic acquisitions.

The method of payment is stored in a dummy variable (CASH) which takes a value of one whether the acquisition is entirely financed with cash or equivalents). Travlos (1987) shows that cash-financed deals generate higher announcement abnormal returns.

A dummy variable (PUBLIC) takes the value of one when the target is a publicly traded company: examining a sample of U.S. bidders, Chang (1998) shows that bidder abnormal returns are higher when the target is privately held. This result appears to be universal as Faccio et al. (2006) observe similar patterns for transactions initiated by European companies.

The relative size of the deal (REL. SIZE) is taken into account. In the spirit of Faccio and Masulis (2005), I compute the ratio of the deal value over the sum of deal value and bidder's market value of equity at the end of the year preceding the announcement of the deal. Moeller et al. (2004) observe a positive association between relative size and bidders' announcement abnormal returns but this result seems to be largely driven by the smallest bidders.

A measure of recent mergers and acquisitions activity in the target industry (INDUSTRY M\&A) is computed following Schlingemann et al. (2002). Moeller et al. (2004) document lower abnormal returns for bidders acquiring firms in the most active mergers and acquisitions markets. The INDUSTRY M\&A variable is calculated for the year preceding the announcement.

As an additional control variable, I include a proxy for Tobin's Q (TOBIN'S Q) and the natural logarithm of the book value of assets (LOG(ASSETS)) as Moeller et al. (2004) find evidence of negative associations between abnormal returns and these two variables.

\subsubsection{Analysis of the propensity to engage in acquisitions: control variables}

Faccio and Masulis (2005) estimate a Probit model to predict bidders. The explanatory power of their models is quite high, with McFadden $\mathrm{R}^{2}$ values around $20 \%$. I hence choose to rely on their methodology and include in my regressions most of their control variables. I include Tobin's Q and the ratio of tangible assets - property, plants and equipments - to total assets (PPE/ASS). A positive association between these two variables and the likelihood of bidding is expected, as both variables make the financing of the deal easier: property plants and equipments can serve as collateral if additional borrowing is required while a high 
Tobin's Q makes acquisition cheaper in case of a stock-financed deal. Shleifer and Vishny (2003) propose a theory of acquisitions based on valuations and show that firms are more likely to make stock-financed acquisition when their shares are overvalued.

Harford (1999) and Miller et al. (2010) respectively find evidence of a positive impact of firm growth and firm size on the acquisition likelihood. Assets growth (ASSETS GROWTH) and the logarithm of the book value of assets are included as additional control variables.

One of the main motivations of managers who choose to list abroad is a better access to funds (Bancel and Mittoo, 2001) which can be especially useful for the financing of an acquisition. Faccio and Masulis (2005) demonstrate that firms which are cross-listed on either the London Stock Exchange or the New-York stock-exchange are more frequent bidders. I construct a dummy variable (LISTING USA) which takes the value of one when the firm has a listing on a major U.S. stock exchange (Nyse, Amex or Nasdaq). They also show that firms classified as belonging to the high tech sector are more likely to become bidders, I hence include such a dummy variable (HIGH TECH). As a positive association between takeover activity on the firm's sector and bidding likelihood is also expected, INDUSTRY M\&A is included as an additional control variable.

I take into account the debt of the bidding company (LEVERAGE): firms exhibiting a high leverage may be financially constrained and may find it difficult to finance an acquisition.

According to Jensen (1986), the cash holdings of the firm are an important determinant of bidding likelihood. I compute the ratio of cash plus tradable securities over total assets as a measure of corporate cash-holdings. However, data are sometimes missing and the inclusion of this variable reduces the sample size (approximately $10 \%$ of the observations are lost). As a consequence, this variable is not included in my regressions. It is worth mentioning that the inclusion of this variable (when available) does not change the results and that the coefficient of this variable is not significant (results available upon request).

\section{Empirical results}

\subsection{Ownership structure and announcement abnormal returns}




\subsubsection{Descriptive statistics}

Panel A of Table 1 presents summary statistics of the acquisitions sample by announcement year. The average value of the transactions (800€ millions) reported in the SDC database is higher than that observed by Masulis et al. (2007). Some firms are very frequent acquirers as the table shows that 660 acquisitions were announced by 196 different firms. In unreported statistics, I notice that the number of acquisitions over the entire period is 1 for 70 firms, 2 for 36 firms, 3 for 34 firms and 4 or more for 56 firms.

Panel B of table 1 describes the characteristics of the bidders and some characteristics of the deals. The average ultimate cash-flow rights of the largest owner are equal to $23 \%$ while her excess control rights are equal to $7.5 \%$. These figures are significantly lower than those observed in earlier French studies (Boubaker, 2007). This could be due to widely-held firms: they are largely represented in my sample of French bidders (23\% of the sample) whereas such firms weight approximately $9 \%$ of the SBF250 index (Belot, 2010). It is worth noting that other blockholders own on average $9.5 \%$ of the voting rights, a relatively high stake which could provide them with the incentives to scrutinize the decisions of the largest shareholder. The table also confirms the widespread use of double voting rights (in $65 \%$ of bidding firms) and pyramidal structures (21\% of the acquirers).

\section{[ INSERT TABLE 1 HERE ]}

In table 2, the focus is on the cumulative abnormal returns over the 3-day period surrounding the announcement date $(\mathrm{CAR}(-1,+1))$. The average (median) value is equal to $0.691 \%(0.284 \%)$ and significantly different from 0 at the $1 \%$ level. I hence do not find evidence of short-term wealth destruction attributable to the acquisitions made by French companies over the sample period 2000 through 2009. This result is consistent with that obtained by Bigelli and Mengoli (2004) who observe positive abnormal returns for a sample of Italian bidding firms. In this table, I split the sample according to different characteristics of the deal. In line with previous studies, I show that transactions which induce a diversification and those involving a publicly traded target generate significantly lower abnormal returns. The abnormal returns generated by cash-financed and domestic deals are positive and significant, although not being significantly different from those observed for cross-border and (at least partially) stock-financed deals. 
A sample split according to ownership structure characteristics reveals interesting patterns: firms whose controlling shareholder holds voting rights which strongly exceed her cash-flow rights (HIGH WEDGE=1) earn lower abnormal returns. The difference between the two groups of firms is not far from significance (the unreported p-value for the t-test is equal to 0.147 ). This analysis also shows that firms whose charter does not authorize double voting rights have higher abnormal returns; interestingly firms whose ultimate owner is an individual or a family seem to make better acquisitions (however, the difference between family and non-family firms is not significant). This last result is consistent with previous studies documenting superior performance of family-controlled companies.

\section{[ INSERT TABLE 2 HERE ]}

\subsubsection{Multivariate analysis}

In Table 3, I report the results of regressions which control for different bidder and deal characteristics. The regressions tend to validate the univariate analysis: deals inducing corporate diversification and involving a publicly traded target generate lower abnormal returns. In line with Moeller et al. (2004), my regressions show that acquirer's Tobin's Q and size have a significant and negative impact on abnormal bidder returns.

In regression (1) and (2), the separation of ownership and control is measured with the difference between ultimate voting and cash-flow rights whereas a ratio is used in regression (3). A dummy variable which takes a value of one when the preceding ratio is under its median value is included in regression (4). In this last regression, the squared-value of ultimate cash-flow rights is included in order to control for a potential non-linear effect in the spirit of Morck et al. (1988). It should be noted that the inclusion of this squared value does not modify the results (the coefficient on HIGH WEDGE is negative and significant at the 5\% threshold if the variable $\mathrm{S} 1 \mathrm{UCF}^{\wedge} 2$ is not included in the regression).

The regressions demonstrate that firms exhibiting a high separation of ownership and control earn lower announcement-period abnormal returns. This result supports the hypothesis of private benefits extraction through acquisitions. Large shareholders whose interests are not perfectly aligned with those of minority shareholders seem to be prone to engage in value destroying acquisitions. This result is consistent with that obtained by Bigelli and Mengoli (2004) for Italy but is at odds with previous studies: Holmén and Knopf (2004) or Ben-Amar and André (2006) do not observe any significant impact of the ownership/control discrepancy 
on acquisition quality. It is a priori difficult to bring such contradictory findings back together, however the observed differences may be due to different institutional and legal frameworks. Bigelli and Mengoli's acquiring firms are incorporated in Italy, a civil-law country whose company law was strongly influenced by the French commercial code (La Porta et al., 1998) while Holmén and Knopf (Sweden) and Ben-Amar and André (Canada) study acquisitions initiated in countries with legal rules that are more protective of minority shareholders.

In regression (5), the impact of control enhancing mechanisms is investigated. Double voting rights are associated with significantly lower abnormal returns while pyramids have a negative but insignificant influence. This result is in line with that observed by Villalonga and Amit (2009) who do not find evidence of pyramidal discount and demonstrate that dual-class shares harm firm value. Such findings advocate a mandatory implementation of the one shareone vote principle and cast doubts on the relevance of double voting rights that are so far encountered in a large majority of French listed companies.

Recent studies demonstrate that family-firms are superior performers; I hence add the FAMILY variable and do not observe any significant impact of this variable (unreported regression). In regression (6), the difference between voting and cash-flow rights is interacted with the FAMILY dummy variable. Family ownership tends to offset the negative impact of a high ownership-control discrepancy. It is often assumed that families are prone to extract private benefits at the expense of minority shareholder but my results do not validate this intuition. In unreported regressions, I re-run equation (1) on the sample of family-controlled companies (271 observations) and on the sample of non-family controlled companies (389 obseravtions). The coefficient of the WEDGE variable is always negative but only significant (with a p-value of 0.012 ) in the second sample. In the last column of Table 3, I try to analyse more precisely this last finding: among family-controlled firms, I differentiate between the firms that are run by a professional CEO (F_PRO, 144 observations) and those that are managed by the founder or a descendant (F_FAM, 127 observations). As mentioned above, an important private benefit that is enjoyed by controlling families is the ability to allot significant management positions to family members. The regression shows that the positive impact of family ownership is only attributable to family firms that are managed by a professional CEO, in other words firms in which the family seems to be reluctant to exploit her controlling situation. This result corroborates the study of Sraer and Thesmar (2007) who show that abnormal returns to long-run shareholders of acquirers are higher for family-firms that are managed by an outside CEO. 


\section{[ INSERT TABLE 3 HERE ]}

\subsubsection{The role played by other blockholders}

It is often argued that other blockholders (beyond the biggest shareholder) are likely to play a monitoring role. Laeven and Levine (2008) show that firms exhibiting a complex ownership structure (i.e. having at least two large shareholders, each of them holding at least $10 \%$ of the voting rights) have a higher valuation than firms with a single shareholder. This effect is even more pronounced when the dispersion of the cash-flow rights between large shareholders is small.

I hence try to analyze the effect of other blockholders in table 4. My sample of 660 observations contains 184 deals announced by firms with at least two large shareholders and 354 by firms with one (or more) shareholder holding at least $5 \%$ of the voting rights. In regression (1) to (3), I introduce three variables aimed at capturing the power of outside blockholders. These new specifications do not change the main result: bidder announcement returns are negatively related to the divergence of cash flow rights and control rights of the largest shareholder. These regressions show that other blockholders have a negative impact on the quality of acquisition decisions. In the first regression, the coefficient for S2 UVR is negative and not far from significance (with a p-value of 0.112 ). This result is at odds with that obtained by Ben-Amar and André (2006) who find evidence of a strong and significant impact of outside blockholders; it also contradicts previous studies which document a positive association between performance and the size of other blockholders. ${ }^{10}$ One possible explanation is that other blockholders do not exert adequate monitoring effort; this could be due to a free-rider problem among large shareholders (Winton, 1993). In this context, the presence of multiple blockholders is detrimental to firm value and performance as large blockholders reduce liquidity without offering any offsetting monitoring advantage (Bolton and Von Thadden, 1998).

In order to shed more light on the negative impact of other large blockholders, I now envisage another explanation, namely collusion between large shareholders. Maury and Pajuste (2005) argue that certain shareholders' coalitions can actually reduce the marginal cost of stealing and make the diversion of resources easier thanks to extra knowledge in hiding expropriation. Bennedsen and Wolfenzon (2000) consider a coalition formation game

\footnotetext{
${ }^{10}$ For instance, a recent study by Attig et al. (2008) shows that the cost of equity capital decreases as the stake of other large blockholders increases.
} 
where the members of the winning coalition share private benefits of control among themselves. In the context of this paper, the negative impact of other blockholders on abnormal returns may be attributable to their propensity to collude with the largest owner in order to share the private benefits that are derived from the acquisition.

Identifying the existence of such coalitions is not an easy task. However, my focus on France offers an interesting advantage: in French listed companies, some shareholders can be signatories to explicit agreements that govern their relations. Each shareholder agreement must be disclosed to the AMF in the five days following its signature as soon as it concerns at least $0.5 \%$ of the securities or voting rights. This legal rule allows for an accurate knowledge of agreement's provisions, the identity of the contracting shareholders and their ownership stakes. Shareholder agreements appear to be an important phenomenon as they are observed in $21.1 \%$ of my sample of acquiring companies. In a majority of the cases, the largest owner is a signatory to this agreement (in $18.2 \%$ of the observations).

A shareholder pact can contain a large number of clauses regarding the transfer of shares, the management of the company or the allocation of board of director's seats. ${ }^{11}$ A very widespread clause is the concerted action which is defined as an "agreement concluded to acquire or sell voting rights or to exercise these voting rights so as to implement a common policy towards the company". The most important feature of a concerted action is the fact that contracting shareholders express a common will and vision about the firm's strategic decisions, it clearly characterizes a cooperative behavior of the signatories. This very strong commitment is observed in $15.5 \%$ of the sample, that is to say that nearly $75 \%$ of the shareholder pacts contain the concerted action clause. Some authors have analyzed the effects of shareholder agreements and the results are mixed: Chemla et al. (2007) show that they are efficient coordination mechanisms while Gianfrate (2007) views them as entrenchment devices aimed at protecting controlling shareholders from hostile takeovers.

In regressions (4) to (6) of table 4, I include new variables related to shareholder agreements. I first compute a dummy variable (AGREEMENT) which takes a value of one whether some shareholders of the acquiring company are bound to the largest owner by an agreement. I compute the sum of the ultimate voting rights held by (1) large shareholders who are signatories to an agreement with the largest owner (S234 AGREEMENT) and by (2) large shareholders outside the coalition (S234 NoAGREEMENT). By definition, S234 UVR is equal to the sum of S234 AGREEMENT and S234 NoAGREEMENT. In the same spirit, I

\footnotetext{
${ }^{11}$ For a detailed description of shareholder agreements in French listed companies, see Belot (2010).
} 
compute the variables OTHERS AGREEMENT and OTHERS NoAGREEMENT. Interestingly, the previous result seems to be driven by large blockholders who are not bound to the largest one by a shareholder pact. In other words, these regressions suggest that the coalition hypothesis is not accurate for my sample of French companies. My results reject the hypothesis of expropriation by shareholder coalitions, however I do not find evidence of superior performance by acquirers having a shareholder agreement.

\section{[ INSERT TABLE 4 HERE ]}

\subsection{Likelihood of bidding}

\subsubsection{Descriptive statistics}

As mentioned above, my sample of French listed firms contains 3,063 observations. There was a deal announcement in the following year for 497 observations (i.e. 16.2\% of the sample). I first try to analyze the differences between firms which announced an acquisition over the period 2000-2009 and firms which did not. Table 5 presents descriptive statistics and classical tests of differences. The differences between the two subsamples are of expected sign: bidding firms are much bigger, receive a higher valuation and have a higher growth; furthermore they are more frequently cross-listed in the U.S. and classified as high tech companies. The intensity of M\&A in their economic sector is also higher than that observed for their counterparts.

The table also reveals very significant differences in ownership characteristics: the ultimate cash-flow rights of the largest owner are smaller for bidding firms while her entrenchment (as measured by the difference between voting and cash-flow rights) is lower. This tends to shows that controlling shareholder whose control rights strongly exceeds their cash-flow rights are reluctant to make acquisitions. In unreported statistics, I notice that only $6.5 \%$ of non-bidding companies are widely-held firms while they are $19.3 \%$ in the sample of acquirers. This shows that manager-controlled firms (as opposed to owner-controlled companies) are more frequent bidders. The table also reveals that family firms are overrepresented in the sample of non bidding firms, which indicates that families are cautious toward corporate acquisitions. 


\subsubsection{Multivariate analysis}

Table 6 reports the findings from different econometric specifications that incorporate year and sector dummies (these dummies are based on the 1-digit SIC code). The Mc Fadden $\mathrm{R}^{2}$ values are around 15\%, which tends to show that the explanatory power of the Probit models is high. The regressions confirm previous findings regarding the impact of firm size, growth and U.S. listing. Highly leveraged companies are less likely to make acquisition, which can be interpreted as evidence of financial constraint.

Regressions (1) and (2) reveal that ownership has an important influence on the likelihood of corporate acquisitions. The cash-flow rights held by the largest shareholder have a negative impact. This result is consistent with the monitoring hypothesis: shareholders holding high stakes in the company are more likely to scrutinize manager actions and hence avoid valuedestroying acquisitions. The negative impact of the divergence of cash-flow rights and voting rights is more ambiguous: shareholders with sub-optimal incentives (i.e. holding excess control rights) could favor acquisitions that provide them with private benefits of control even if these acquisitions do not enhance firm value. This hypothesis is not validated by the empirical analysis. This result may be explained as follows. The controlling shareholder's voting power may be threaten by stock-financed corporate acquisitions which induce significant changes in the ownership structure. Because they significantly reduce corporate cash-holdings and/or borrowing capacities, even cash-financed acquisitions may lead to future equity offerings. Shareholders with excess control rights may be very cautious toward corporate acquisitions, being aware of the relinquishment to control (and hence to associated private benefits) that such acquisitions induce.

In regression (3), I analyze the impact of other blockholders. The coefficient of the OTHERS variable is negative but insignificant, which demonstrates that these blockholders do not play an active role in avoiding or favoring corporate acquisitions. In unreported regressions, I include the control rights of the second largest owner (S2 UVR) and the control rights of other large shareholders (S234 UVR) and do not observe significant coefficients.

An unreported regression shows that the coefficient associated on FAMILY is not significant. In regression (4), I include two variables aimed at capturing the impact of family ownership: the results show that family firms whose CEO is not a family member are more prone to make acquisition. The coefficient of the F_FAM variable is negative (but insignificant): one possible explanation is that family CEOs are not successful in complex acquisitions and are reluctant to attempt such acquisitions. 
Regression (5) confirms previous findings: the relative size of the acquisitions is negatively associated with largest shareholder's cash flow rights and her excess control rights. In the last column, I exclude bidding firms which are classified as banks or insurance companies as it is often argued that these financial companies have accounting data that are difficult to compare with firms in other sectors. The main results concerning the influence of ownership characteristics are unaffected.

My results are in line with the European study of Caprio et al. (2010). The authors also observe a negative association between the ownership/control discrepancy and the propensity to engage in acquisitions. The empirical analysis thus contradicts the pessimistic view of controlling shareholders favoring acquisitions thanks to their excess control rights.

\section{[ INSERT TABLE 6 HERE ]}

\section{Robustness checks}

\subsection{Other specifications}

Table 7 presents different regressions aimed at testing the robustness of previous results. In regression (1), I exclude the deals that are not classified as completed in the SDC database. This makes the results more comparable with those obtained by Ben-Amar and André (2006). This does not change my results, the coefficient on WEDGE RATIO is still positive and significant.

In the second regression, I exclude the firms that are classified as widely-held (i.e. which do not have a controlling shareholder holding at least $10 \%$ of the voting rights). Although being less significant than in the standard regression, the coefficient of the WEDGE variable is still negative.

As mentioned above, some firms are very frequent acquirers and the time period between two deals is sometimes inferior to 200 days (i.e. the length of the time period over which the market model parameters of the event study are estimated). In order to circumvent the contamination effect, I exclude all the acquisitions made by firms which have already announced another deal during the estimation period. The third column of table 7 presents the results. I do not observe significant differences and the main result holds.

In regression (4), I use cumulative abnormal returns computed on a larger event-window $(\operatorname{CAR}(-2,+2))$. This does not lead to significant changes. In unreported regressions, I notice 
that my results holds when the 7-day CAR $(\operatorname{CAR}(-3,+3))$ are used as the dependant variable. In regression (5), I run a Logit model with the dependant variable taking the value of one when $\operatorname{CAR}(-2,+2)$ are lower than $0 .{ }^{12}$ In the spirit of Masulis et al. (2009), this specification allows to test whether acquisitions initiated by firms whose largest shareholder is entrenched generate negative abnormal returns and destroy shareholder value. This regression clearly shows that it is the case.

In unreported tests, I re-run the regressions of table 3 by adding the variables that are included in the Probit model to determine the likelihood of bidding (leverage, assets growth, proportion of tangible assets, U.S. listing, high tech dummy). The coefficients of the variables measuring the separation of ownership and control are stable and remain significant. The coefficients of the added variables are all insignificant except the one associated with the ratio of tangible assets over total assets (the coefficient is significantly negative).

\section{[ INSERT TABLE 7 HERE ]}

\subsection{Sample selection bias}

In the first part of the paper, I analyze the relationship between ownership structure and the short-term financial impact of corporate acquisitions. The sample is not randomly chosen in that it only consists of firms which choose to make at least one acquisition over the 20002009 decade. The second part of the paper shows that these firms differ in many ways from firms which never experience acquisitions. To address a potential sample selection bias, I employ the Heckman's (1979) two step procedure. In the first step, I estimate a Probit model whose dependant variable takes the value of one whether the firm announces a bid. I then compute the inverse Mills ratio for each observation of the sample. ${ }^{13}$ In the second step, I run the previous OLS regressions (with CAR $(-1,+1)$ as the dependant variable) and include the inverse Mills' ratio as an additional explanatory variable. If this variable has an insignificant coefficient, one can conclude that sample selection bias is not a major issue and hence that there is no over or underestimation of the coefficients.

I first construct the inverse Mills ratio (INV MILLS) based on the coefficient estimates from regression (2) of table 6 and include it as an additional explanatory variable in my

\footnotetext{
${ }^{12}$ It is worth mentioning that nearly half of the deals generate negative abnormal returns: the dependant variable is equal to one in $49.1 \%$ of the sample.

${ }^{13}$ For a detailed description of selection problems, see Chapter 17 of Wooldridge (2002).
} 
analysis of bidders' announcement abnormal returns. The results are presented in the sixth column of table 7 . In the last column, I repeat this analysis for the subsample of non-financial firms with the inverse Mills ratio based on Probit estimates from table 6 (regression (6)).

In the last regression, the coefficient of the inverse Mills ratio is not significant at conventional threshold. Consequently, selection bias does not appear as a serious concern for my estimates. Furthermore, the results hold when financial companies are excluded.

The coefficient on INV MILLS is positive and marginally significant in the sixth column. This suggests that it is important to control for sample selection bias. I observe that the coefficient on WEDGE RATIO is now significant at the 5\% threshold; it also appears that the coefficient on LOG ASSETS is no longer significant. The interpretation of the results is the following: the empirical analysis demonstrates that firms with a high ownership/control discrepancy earn lower abnormal returns (Table 3) while being also less frequent bidders (see Table 6). In other words, such firms are under-represented in the acquisition sample and the negative impact of the difference between voting and cash-flow rights on CARs might be underestimated in standard OLS regressions. It also appears that the coefficient on the size variable is no longer significant, big firms being overrepresented in the acquisition sample and hence the coefficient on LOG ASSETS overestimated in OLS regressions linking size to abnormal returns.

Even if the coefficient on inverse Mills ratio (IMR) is only marginally significant, sample selection bias appears to be an important issue. I hence include IMR in all previous regressions, the results hold and the magnitude of coefficients on WEDGE or WEDGE RATIO is larger (results are available upon request). This studies advocates for sample selection corrections as the coefficients estimates of earlier studies might be biased: BenAmar and André (2006) do not find that separation of ownership and control has a negative impact on performance, this could be due to sample selection problems as bidders are not randomly selected from the entire population of listed companies.

\subsection{Endogeneity}

\subsubsection{Endogeneity, part 1}

So far, my results suggests that controlling owners use their excess control right to favor acquisitions that are in their own interests. These acquisitions provide them with private benefits of control that are not available to all shareholders. However, my results should be 
interpreted cautiously as studies dedicated to ownership structures may be susceptible to endogeneity concerns.

The relationship between ownership structure and performance has received considerable attention in financial literature. Many studies (see Demsetz and Villalonga [2001] for a detailed survey) estimate an equation whose dependant variable is a proxy for corporate performance (Tobin's Q, ROA...) while regressors are control (size of the company, financial leverage...) and ownership (insider holdings, identity of the largest owner...) variables. Some authors argue that ownership characteristics are not randomly determined and there are serious reasons to believe that ownership emerges as a response to firm's characteristic and environment (Demsetz and Lehn, 1985). For instance, market capitalization is a potential determinant of corporate performance but might also explain the presence and size of a large blockholder (the wealth needed to hold a substantial stake in General Electric makes the presence of a large blockholder not likely). Furthermore, ownership characteristics are likely to be correlated with (omitted) factors that also affect performance: Demsetz and Lehn argue that a concentrated ownership structure is more likely to emerge when there is amenity potential associated with the control of the company. Such private benefits might affect both corporate performance and ownership characteristics: a large shareholder could indeed be willing to increase her voting rights while decreasing her cash-flow rights when the opportunities for private benefits extraction are greater. To sum up, endogeneity concerns make the interpretation of standard regressions difficult: ownership variables might indeed be correlated with the error terms and the coefficient estimates of single equation models of the effect of ownership structure on corporate performance might be severely biased.

To mitigate such endogeneity problem, instrumental variables (IV) are commonly used in financial and accounting research. As emphasized by Angrist and Krueger (2001), a valid instrument needs to fulfill two conditions: "a good instrument is correlated with the endogenous regressor for reasons the researcher can verify and explain, but uncorrelated with the outcome variable for reasons beyond its effect on the endogenous regressor". In this paper, the key variable of interest is the difference between voting and cash-flow rights of the controlling shareholder. I attempt to determine which variables meet the following criteria: (1) they have a significant influence on the WEDGE variable and (2) they do not affect the dependant variable (acquisitions' quality proxied by the CARs) directly but only through their influence on the endogenous variable (WEDGE).

The first variable I consider is the number of years since firm's first listing on the stock market (proxied by the first year the firm appears in Datastream). One argument is the 
following: recently listed companies must attract (international) investors and have a higher interest in good corporate governance. They face a growing pressure for compliance with codes of best practices; the double-voting rights mechanism which contradicts the one shareone vote rule is clearly not a good governance principle. In my acquisition sample, bidders with double voting rights have been listed for 17.3 years (vs. 12.2 years for others bidders, the difference being significant at the $1 \%$ threshold). Furthermore, firms that have been listed for a long period of time are more likely to exhibit pyramidal structure, this being due to the larger number of complex events (mergers for instance) involving ownership changes they have experienced. In the acquisition sample, bidders exhibiting a pyramidal structure have been listed for 17.3 years (versus 15.0 years for other firms, the difference being significant at the $5 \%$ threshold). The question whether this variable might directly affect firm performance arises. Moeller et al. (2004) notice that firm age has no significant impact on announcement abnormal returns. I repeat this analysis by including the age variable and draw the same conclusion. It is worth mentioning that such an "historical" instrument has been used by Fahlenbrach (2009) in a study dedicated to the impact of founder-CEOs on corporate performance.

The second variable I consider is aimed at capturing amenity potential of a firm's output. In a study dedicated to dual-class companies in the U.S., Gompers et al. (2010) argue that the choice of the dual-class structure (and hence the choice of a high separation of ownership and control) is not random and driven by variables capturing various forms of private benefits. One of the measures is the ratio of firm's sales to the sales of all firms in the same geographic region. The underlying reasoning is the following: there are private benefits (especially prestige and social status) associated with the fact of being a big employer and a well-know citizen of a local community. Roosenboom and Schramade (2006) show that owner-managers are more likely to lock control when the firm has its headquarters outside Paris, Lyon, Marseille and Lille (the four biggest French cities). To compute my variable (PCT SALES), I use the following procedure: I first extract (from the Worldscope database) the postal codes and sales of all French firms that have been listed over the years 1999-2008. ${ }^{14}$ I then classify them according to the first two digits of this postal code which identify the "département" where the firm has its headquarters. ${ }^{15}$ In the acquisition sample, the average value of the PCT SALES variable is equal to $10.8 \%$ for firms having a high separation of ownership and

\footnotetext{
${ }^{14}$ I do not require these firms to be components of the SBF250 index. I hence consider 1,245 unique French firms that have been listed for at least one year over the period 1999-2008.

${ }^{15}$ There are 100 départements in France, this administrative zoning was drawn around 1800.
} 
control (HIGH WEDGE=1) whereas being equal to $8.1 \%$ for other firms (nevertheless, the difference is only significant at the $15 \%$ threshold). In my opinion, there is no reason to suspect that corporate performance is related to the localization of the company's headquarters. For instance, one could difficultly argue that firms located in area X record better performance than those located in area Y: France is a well developed economy and public infrastructure are adequate for all geographic areas. One could also argue that controlling shareholder with high power and social prestige in a given geographic area may get favors from local politicians, which could have an impact on firm performance. This is however not a major issue: Faccio (2006) shows that only $2.19 \%$ of French firms are politically connected (the world average is equal to $2.68 \%$ ); furthermore the performance of politically connected firms tends to be lower (Faccio, 2010). I include the PCT SALES variable in my regressions and do not observe any significant impact on firm's performance as proxied by cumulative abnormal returns around the announcement of an acquisition.

I use the standard two-stage least squares (2SLS) methodology. In the first stage, I regress the endogenous right-hand side variable (WEDGE) on the set of chosen instruments. In the second stage, the predicted (instrumented) values of WEDGE are introduced in the baseline regressions. Table 8 presents the results of this empirical analysis. The first two columns report the results obtained on the whole acquisition sample, whereas regressions (3) and (4) are estimated with the deals that are not classified as completed in the SDC database. Regression (5) is estimated using the sample of firms having at least one large shareholder, with a second stage dependant variable taking the value of one when cumulative abnormal returns around the announcement date are negative. ${ }^{16}$

First, it appears that the selected instrument have a strong influence in explaining the separation of ownership and control. Old firms and firms having a large economic importance in their geographic area are more likely to exhibit an important ownership/control discrepancy. The table shows that the new specifications do not significantly change the coefficient estimates of the control variables. It also appears that the coefficient on WEDGE is negative and significant in columns (2) to (4). It should be noted that the p-value associated to the instrumented regressor in regression (1) is equal to $12.8 \%$. Regression (5) confirms previous findings: the probability of a negative market reaction to the announcement of an acquisition is increasing in the wedge between voting and cash-flow rights of the largest shareholder.

\footnotetext{
${ }^{16}$ As the dependant variable in the second stage is an indicator variable, I use the ivprobit command of STATA 10 to estimate regression (5).
} 
Be that as it may, it should be mentioned that the identification of the right instrument is a difficult and risky task. Bennedsen and Nielsen (2010) discuss the quality of variables aimed at instrumenting ownership-control disproportionality. They conclude that they lack qualified instruments for an IV analysis. More generally, Larcker and Rusticus (2010) demonstrate that many instrumental variables applications in accounting and financial research are likely to produce highly misleading parameter estimates. Coles et al. (2007) illustrate the difficulties in choosing appropriate instrument in studies dedicated to the ownership-performance relationship.

Conventional tests (Sargan statistic and $\mathrm{J}$ test) for overidentifying restrictions validate the null hypothesis of instruments uncorrelated with the error terms; moreover I examine the fit of the first stage and reject the null hypothesis of weak instruments in all the reported regressions. ${ }^{17}$ Although these tests tend to demonstrate the appropriateness of the instruments, the results should be interpreted cautiously. Wooldridge (2002) points out potential large biases of 2SLS and recalls that "we must choose between a possibly inconsistent estimator that has relatively small standard errors $(O L S)$ and a consistent estimator that is so imprecise that nothing interesting can be concluded" (p. 104). This could explain why the coefficient estimates are sometimes less significant than with OLS regressions. Be that as it may, the negative coefficient of the WEDGE variable in regressions (1) to (4) confirms the results that were obtained with standard OLS regressions.

\section{[ INSERT TABLE 8 HERE ]}

\subsubsection{Endogeneity, part 2}

One form of the endogeneity problem is reverse causality. If we assume that controlling shareholders (1) use acquisitions as means of extracting private benefits and (2) anticipate future acquisitions, they could be likely to modify their ownership (and control) stakes exante. The reasoning is the following: anticipating future bad acquisitions (i.e. with negative CARs), they could be tempted to increase their control rights (they can hence use these voting rights in order to favor the achievement of the deal) and reduce their cash-flow rights (in order to minimize the decrease in their net wealth induced by the value-destroying acquisition). However, I do not find evidence of such an opportunistic behavior. Previous year ownership

\footnotetext{
${ }^{17}$ See Baum (2006) for an accurate description of the tests that can be performed in order to check the validity of instruments.
} 
variables are available for 560 observations of my acquisition sample; the WEDGE variable is equal to $7.00 \%$ in year $t$ and $7.03 \%$ in year $t-1$ (the difference is not significant, with a p-value of 0.90). To further address the reverse causality concern, I replace the annual values of S1 UCF and WEDGE in year $t$ with their values in the first year the firm appears in my sample (following Masulis et al. [2009] who use such a specification). This additional test does not change the results.

\section{Conclusion}

This paper investigates an important financial decision, namely corporate acquisitions, and how the ownership structure of the firm affects (1) abnormal returns around announcement date and (2) the propensity to launch a takeover bid. The results clearly demonstrate that minority shareholders of firms whose largest shareholder holds excess control rights experience lower abnormal returns. This result is robust to sample selection bias that has not been taken into account in earlier studies.

This paper contributes to the ongoing debate on the one share-one vote principle. Institutional investors request the suppression of double voting rights (see for instance the recommendations of the association which represents the French asset management industry AFG, 2010). However, prominent CEOs advocate that this violation of the one share - one vote principle protects the firm against the influence of short term investors (see the recent viewpoint expressed by Claude Bébéar (2008), former CEO and chairman of AXA). Burkart and Lee (2008) question the relevance of French double voting rights. This paper clearly demonstrates that double voting rights comes at a cost as firms authorizing this mechanism experience lower abnormal returns around acquisition announcements. 


\section{Appendix A: The ownership structure of GROUPE CASINO}

This figure presents the ownership structure of GROUPE CASINO as of December 31, 2007. Firms in grey boxes are publicly traded firms. The control of GROUPE CASINO is realized through an extensive use of double voting rights (encountered in GROUPE CASINO / RALLYE / FONCIERE EURIS) and pyramiding. Non-voting shares account for $13.50 \%$ of GROUPE CASINO's existing equities.

Following La Porta et al. (1999), I consider that the Naouri family is the ultimate controlling owner of GROUPE CASINO (at the apex of the pyramid). In line with Faccio and Lang (2002), I consider that this ultimate owner holds ultimate cash-flow rights equal to $23.09 \%$ $(=99.99 \% * 92.15 \% * 88.78 \% * 57.28 \% * 49.28 \%)$ and ultimate voting rights equal to $62.32 \%$ $(\min \{99.99 \%, 92.16 \%, 91.07 \%, 71.44 \%, 62.32 \%\})$.

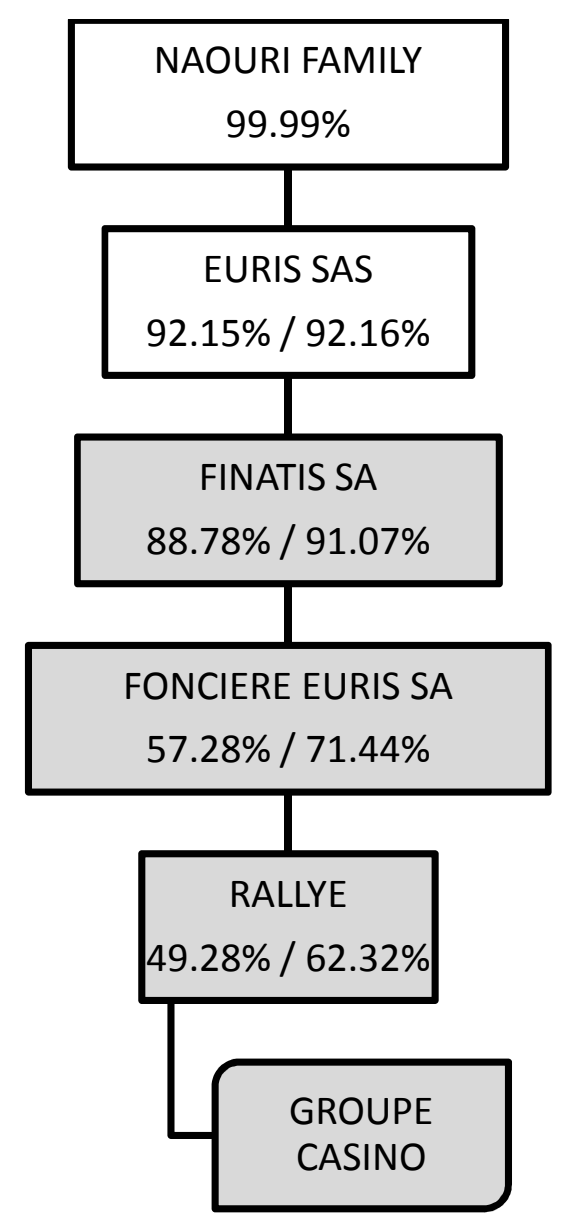




\section{Appendix B: Description of the variables}

\begin{tabular}{|c|c|}
\hline AGREEMENT & $\begin{array}{l}\text { Equals } 1 \text { if a shareholder agreement is in force in the acquiring firm, } 0 \\
\text { otherwise. Source: Author's database. }\end{array}$ \\
\hline $\begin{array}{l}\text { ASSETS } \\
\text { GROWTH }\end{array}$ & $\begin{array}{l}\text { Bidder's growth rate of total assets in the year preceding the announcement of } \\
\text { the bid. Source: Author's calculations based on data from Worldscope. }\end{array}$ \\
\hline CASH & Equals 1 if the transaction is entirely paid with cash, 0 otherwise. Source: SDC. \\
\hline CROSS BORDER & $\begin{array}{l}\text { Equals } 1 \text { if the target company is not incorporated in bidder's country of } \\
\text { incorporation, } 0 \text { otherwise. Source: SDC. }\end{array}$ \\
\hline DIVER & $\begin{array}{l}\text { Equals } 1 \text { if acquiring and target firms do not have the same 2-digit SIC code, } 0 \\
\text { otherwise. Source: SDC. }\end{array}$ \\
\hline DVR & $\begin{array}{l}\text { Equals } 1 \text { if double voting rights are authorized by the company's charter, } 0 \\
\text { otherwise. Source: Author's database. }\end{array}$ \\
\hline FAMILY & $\begin{array}{l}\text { Equals } 1 \text { if the ultimate owner of the company is an individual or a family, } 0 \\
\text { otherwise. Source: Author's database. }\end{array}$ \\
\hline F_PRO & $\begin{array}{l}\text { Equals } 1 \text { if (1) the ultimate owner of the company is an individual or a family } \\
\text { and (2) the CEO is not a member of this family (i.e. the CEO is a professional } \\
\text { manager), } 0 \text { otherwise. Source: Author's database. }\end{array}$ \\
\hline F_FAM & $\begin{array}{l}\text { Equals } 1 \text { if (1) the ultimate owner of the company is an individual or a family } \\
\text { and (2) the firm is managed by a member of this family, } 0 \text { otherwise. Source: } \\
\text { Author's database. }\end{array}$ \\
\hline HIGH TECH & $\begin{array}{l}\text { Equals } 1 \text { when the primary SIC Code of the firm is } 3571-2-5-7-8,3661-3-9 \text {, } \\
3674,3812,3823-5-6-7-9,4899 \text { or } 7370-1-2-3-4-5-9 \text { (Faccio and Masulis, } \\
2005 \text { ), 0 otherwise. Source: Author's calculations based on data from } \\
\text { Worldscope. }\end{array}$ \\
\hline HIGH WEDGE & $\begin{array}{l}\text { Equals } 1 \text { when the variable WEDGE RATIO is lower than its median value, i.e. } \\
\text { when there is a strong divergence of voting and cash-flow rights; } 0 \text { otherwise. } \\
\text { Source: Author's database. }\end{array}$ \\
\hline INDUSTRY M\&A & $\begin{array}{l}\text { Computed as the value of all corporate control transactions reported by SDC for } \\
\text { each year and two-digit SIC code divided by the total book value of assets of all } \\
\text { Worldscope firms in the same two-digit SIC code and year. Source: Author's } \\
\text { calculations based on data from Worldscope and SDC. }\end{array}$ \\
\hline LEVERAGE & $\begin{array}{l}\text { Ratio of financial debts over total assets at the end of the fiscal preceding the } \\
\text { announcement. Source: Author's calculations based on data from Worldscope. }\end{array}$ \\
\hline LISTING USA & $\begin{array}{l}\text { Equals } 1 \text { when the firm has a listing on a major U.S. stock exchange (Nyse, } \\
\text { Amex or Nasdaq), } 0 \text { otherwise. Source: Datastream. }\end{array}$ \\
\hline LOG(ASSETS) & $\begin{array}{l}\text { Log (Bidder's book value of assets expressed in million euros at the end of the } \\
\text { fiscal preceding the announcement). Source: Author's calculations based on } \\
\text { data from Worldscope. }\end{array}$ \\
\hline OTHERS & $\begin{array}{l}\text { Sum of the ultimate voting rights of all shareholders (except the largest one) } \\
\text { holding at least } 5 \% \text { of the voting rights. Set equal to } 0 \text { when (1) there is no large } \\
\text { shareholder holding at least } 10 \% \text { of the voting rights (i.e. for widely held } \\
\text { companies) or (2) when there is no shareholder holding at least } 5 \% \text { of the voting } \\
\text { rights beyond the largest shareholder. Source: Author's database. }\end{array}$ \\
\hline $\begin{array}{l}\text { OTHERS } \\
\text { AGREEMENT }\end{array}$ & $\begin{array}{l}\text { Sum of the ultimate voting rights of all shareholders (holding at least } 5 \% \text { of the } \\
\text { voting rights) who are signatories to an agreement involving the largest owner. } \\
\text { Set equal to } 0 \text { whether the largest shareholder of the company is not signatory to } \\
\text { a shareholder agreement. Source: Author's database. }\end{array}$ \\
\hline $\begin{array}{l}\text { OTHERS } \\
\text { NoAGREEMENT }\end{array}$ & $=$ OTHERS - OTHERS AGREEMENT. Source: Author's database. \\
\hline PPE/ASS & $\begin{array}{l}\text { Ratio of property, plants and equipments over total assets at the end of the fiscal } \\
\text { year preceding the announcement. Source: Author's calculations based on data } \\
\text { from Worldscope. }\end{array}$ \\
\hline
\end{tabular}




\begin{tabular}{|c|c|}
\hline PCT SALES & $\begin{array}{l}\text { Ratio of firm's sales to the sales of all firms in the same "département" (a } \\
\text { French geographic area). Source: Author's calculations based on data from } \\
\text { Worldscope. }\end{array}$ \\
\hline PUBLIC & Equals 1 if the target is a publicly traded company, 0 otherwise. Source: SDC. \\
\hline PYRAMID & $\begin{array}{l}\text { Equals } 1 \text { when the firm is controlled through a pyramidal structure, } 0 \text { otherwise } \\
\text { (source: Author's database) }\end{array}$ \\
\hline REL. SIZE & $\begin{array}{l}\text { Computed as the ratio [deal value/(deal value + bidder's market capitalization at } \\
\text { the end of the fiscal year preceding the announcement)]. Source: Author's } \\
\text { calculations based on data from Datastream and SDC. }\end{array}$ \\
\hline S1 UCF & $\begin{array}{l}\text { Ultimate cash-flow rights of the largest owner, computed at the } 10 \% \text { threshold. } \\
\text { Set equal to } 0 \text { if there is no shareholder holding at least } 10 \% \text { of the voting } \\
\text { rights. Source: Author's database. }\end{array}$ \\
\hline $\mathrm{S} 1 \mathrm{UCF}^{\wedge} 2$ & $=(\text { S1 UCF })^{2}$. Source: Author's database. \\
\hline S2 UVR & $\begin{array}{l}\text { Ultimate voting rights of the second large owner, computed at the } 10 \% \\
\text { threshold. Set equal to } 0 \text { if there is no second large shareholder holding at least } \\
10 \% \text { of the voting rights. Source: Author's database. }\end{array}$ \\
\hline S234 UVR & $\begin{array}{l}\text { The sum of the ultimate voting rights of the second, third, and fourth largest } \\
\text { shareholders (holding at least } 10 \% \text { of the voting rights). Set equal to } 0 \text { if there is } \\
0 \text { or only one large shareholder. Source: Author's database. }\end{array}$ \\
\hline $\begin{array}{l}\text { S234 } \\
\text { AGREEMENT }\end{array}$ & $\begin{array}{l}\text { The sum of the ultimate voting rights of large blockholders (holding at least } \\
10 \% \text { of the voting rights) who are signatories to a shareholder agreement } \\
\text { involving the largest owner. Set equal to } 0 \text { whether the largest shareholder of } \\
\text { the company is not signatory to a shareholder agreement. Source: Author's } \\
\text { database. }\end{array}$ \\
\hline $\begin{array}{l}\text { S234 } \\
\text { NoAGREEMENT }\end{array}$ & = S234 UVR - S234 AGREEMENT. Source: Author's database. \\
\hline TOBIN'S Q & $\begin{array}{l}\text { Computed as the ratio [(bidder's total assets + bidder's market capitalization - } \\
\text { bidder's book value of equity)/bidder's total assets] at the end of the fiscal year } \\
\text { preceding the announcement. Source: Author's calculations based on data from } \\
\text { Worldscope. }\end{array}$ \\
\hline WEDGE & $\begin{array}{l}\text { = Ultimate voting rights of the largest owner (computed at the } 10 \% \text { threshold) }- \\
\text { S1UCF. Source: Author's database. }\end{array}$ \\
\hline WEDGE RATIO & $\begin{array}{l}\text { = S1UCF / Ultimate voting rights of the largest owner (computed at the } 10 \% \\
\text { threshold). Source: Author's database. }\end{array}$ \\
\hline YEARS IPO & $\begin{array}{l}\text { Number of years between the deal and the first year the firm appears in } \\
\text { Datastream. Source: Datastream. }\end{array}$ \\
\hline
\end{tabular}




\section{Bibliography}

AFG (Association Française de Gestion), 2010. Recommendations on corporate governance. Available at: http://www.afg.asso.fr.

Almeida, H.V. \& Wolfenzon, D., 2006. A theory of pyramidal ownership and family business groups. Journal of Finance, 61(6), 2637-2680.

Amihud, Y. \& Lev, B., 1981. Risk reduction as a managerial motive for conglomerate mergers. Bell Journal of Economics, 12(2), 605-617.

Anderson, R.C. \& Reeb, D.M., 2003. Founding-family ownership and firm performance: Evidence from the S\&P 500. Journal of Finance, 58(3), 1301-1328.

Angrist, J.D. \& Krueger, A.B., 2001. Instrumental variables and the search for identification: From supply and demand to natural experiments. Journal of Economic Perspectives, 15(4), 69-85.

Attig, N., Guedhami, O. \& Mishra, D., 2008. Multiple large shareholders, control contests, and implied cost of equity. Journal of Corporate Finance, 14(5), 721-737.

Bae, K., Kang, J. \& Kim, J., 2002. Tunneling or value added? Evidence from mergers by Korean business groups. Journal of Finance, 57(6), 2695-2740.

Ball, R. \& Brown, P., 1968. An empirical evaluation of accounting income numbers. Journal of Accounting Research, 6(2), 159-178.

Bancel, F. \& Mittoo, C.R., 2001. European managerial perceptions of the net benefits of foreign stock listings. European Financial Management, 7(2), 213-236.

Baum, C.F., 2006. An introduction to modern econometrics using Stata, Stata Press.

Bebchuk, L., Kraakman, R. \& Triantis, G., 2000. Stock pyramids, cross-ownership, and dual class equity: The creation and agency costs of separating control from cash flow rights. In Concentrated Corporate Ownership. University of Chicago Press: Randall K. Morck ed., pp. 295-315.

Bébéar, C., 2008. Non à la suppression des actions à droit de vote double. Les Echos.

Belot, F., 2010. Shareholder agreements and firm value: Evidence from French listed firms. Available at: http://papers.ssrn.com/sol3/papers.cfm?abstract_id=1282144.

Ben-Amar, W. \& André, P., 2006. Separation of ownership from control and acquiring firm performance: The case of family ownership in Canada. Journal of Business Finance \& Accounting, 33(3/4), 517-543.

Bennedsen, M. \& Nielsen, K.M., 2010. Incentive and entrenchment effects in European ownership. Journal of Banking \& Finance, 34(9), 2212-2229. 
Bennedsen, M. et al., 2007. Inside the family firm: The role of families in succession decisions and performance. Quarterly Journal of Economics, 122(2), 647-691.

Bennedsen, M. \& Wolfenzon, D., 2000. The balance of power in closely held corporations. Journal of Financial Economics, 58(1/2), 113-139.

Bertrand, M., Mehta, P. \& Mullainathan, S., 2002. Ferreting out tunneling: An application to Indian business groups. Quarterly Journal of Economics, 117(1), 121-148.

Bigelli, M. \& Mengoli, S., 2004. Sub-optimal acquisition decisions under a majority shareholder system. Journal of Management \& Governance, 8(4), 373-405.

Bloch, F. \& Hege, U., 2001. Multiple shareholders and control contests. Available at: http://www.greqam.fr/spip.php?article6044\&lang=fr.

Bolton, P. \& Von Thadden, E., 1998. Blocks, liquidity, and corporate control. Journal of Finance, 53(1), 1-25.

Boubaker, S., 2007. Ownership-control discrepancy and firm value: Evidence from France. Multinational Finance Journal, 11(3/4), 211-252.

Brown, S.J. \& Warner, J.B., 1980. Measuring security price performance. Journal of Financial Economics, 8(3), 205-258.

Burkart, M., Gromb, D. \& Panunzi, F., 1997. Large shareholders, monitoring, and the value of the firm. Quarterly Journal of Economics, 112(3), 693-728.

Burkart, M. \& Lee, S., 2008. One share-one vote: The theory. Review of Finance, 12(1), 1-49.

Buysschaert, A., Deloof, M. \& Jegers, M., 2004. Equity sales in Belgian corporate groups: expropriation of minority shareholders? A clinical study. Journal of Corporate Finance, 10(1), 81-103.

Caprio, L., Croci, E. \& Del Giudice, A., 2010. Ownership structure, family control, and acquisition decisions. Available at: http://papers.ssrn.com/sol3/papers.cfm?abstract_id=1293853.

Chang, S., 1998. Takeovers of privately held targets, methods of payment, and bidder returns. Journal of Finance, 53(2), 773-784.

Chemla, G., Habib, M.A. \& Ljungqvist, A., 2007. An analysis of shareholder agreements. Journal of the European Economic Association, 5(1), 93-121.

Claessens, S. et al., 1999. Corporate diversification in East Asia: the role of ultimate ownership and group affiliation. Available at: http://papers.ssrn.com/sol3/papers.cfm?abstract_id=615021.

Claessens, S. et al., 2002. Disentangling the incentive and entrenchment effects of large shareholdings. Journal of Finance, 57(6), 2741-2771. 
Claessens, S., Djankov, S. \& Lang, L.H., 2000. The separation of ownership and control in East Asian Corporations. Journal of Financial Economics, 58(1/2), 81-112.

Coles, J.L., Lemmon, M.L. \& Meschke, F., 2007. Structural models and endogeneity in corporate finance: the link between managerial ownership and corporate performance. Available at: http://papers.ssrn.com/sol3/papers.cfm?abstract_id=423510.

Cronqvist, H. \& Nilsson, M., 2003. Agency costs of controlling minority shareholders. Journal of Financial \& Quantitative Analysis, 38(4), 695-719.

Demsetz, H. \& Lehn, K., 1985. The structure of corporate ownership: causes and consequences. Journal of Political Economy, 93(6), 1155-1177.

Demsetz, H. \& Villalonga, B., 2001. Ownership structure and corporate performance. Journal of Corporate Finance, 7(3), 209-233.

Denis, D.J. \& Sarin, A., 1999. Ownership and board structures in publicly traded corporations. Journal of Financial Economics, 52(2), 187-223.

Denis, D.K. \& McConnell, J.J., 2003. International corporate governance. Journal of Financial \& Quantitative Analysis, 38(1), 1-36.

Djankov, S. et al., 2008. The law and economics of self-dealing. Journal of Financial Economics, 88(3), 430-465.

Dyck, A. \& Zingales, L., 2004. Private benefits of control: An international comparison. Journal of Finance, 59(2), 537-600.

Faccio, M., 2010. Differences between politically connected and nonconnected firms: A cross-country analysis. Financial Management, 39(3), 905-928.

Faccio, M., 2006. Politically connected firms. American Economic Review, 96(1), 369-386.

Faccio, M. \& Lang, L.H., 2002. The ultimate ownership of Western European corporations. Journal of Financial Economics, 65(3), 365-395.

Faccio, M. \& Masulis, R.W., 2005. The choice of payment method in European mergers and acquisitions. Journal of Finance, 60(3), 1345-1388.

Faccio, M., McConnell, J.J. \& Stolin, D., 2006. Returns to acquirers of listed and unlisted targets. Journal of Financial \& Quantitative Analysis, 41(1), 197-220.

Faccio, M. \& Stolin, D., 2006. Expropriation vs. proportional sharing in corporate acquisitions. Journal of Business, 79(3), 1413-1444.

Fahlenbrach, R., 2009. Founder-CEOs, investment decisions, and stock market performance. Journal of Financial \& Quantitative Analysis, 44(2), 439-466.

Gianfrate, G., 2007. What do shareholders' coalitions really want? Evidence from Italian voting trusts. Corporate Governance: An International Review, 15(2), 122-132. 
Ginglinger, E. \& Hamon, J., 2009. Ownership, control and market liquidity. Available at: http://papers.ssrn.com/sol3/papers.cfm?abstract_id=1071624.

Gompers, P.A., Ishii, J. \& Metrick, A., 2010. Extreme governance: An analysis of dual-class firms in the United States. Review of Financial Studies, 23(3), 1051-1088.

Guedhami, O. \& Mishra, D., 2009. Excess control, corporate governance and implied cost of equity: International evidence. Financial Review, 44(4), 489-524.

Harford, J., 1999. Corporate cash reserves and acquisitions. Journal of Finance, 54(6), 19691997.

Heckman, J.J., 1979. Sample selection bias as a specificatin error. Econometrica, 47(1), 153161.

Holderness, C.G., 2009. The myth of diffuse ownership in the United States. Review of Financial Studies, 22(4), 1377-1408.

Holmén, M. \& Knopf, J.D., 2004. Minority shareholder protections and the private benefits of control for Swedish mergers. Journal of Financial \& Quantitative Analysis, 39(1), 167-191.

Hubbard, R.G. \& Palia, D., 1995. Benefits of control, managerial ownership, and the stock returns of acquiring firms. RAND Journal of Economics, 26(4), 782-792.

ISS, Sherman \& Sterling \& ECGI, 2007. Report on the proportionality principle in the European Union. Available at: http://www.ecgi.org/osov/final_report.php.

Jensen, M.C., 1986. Agency costs of free cash flow, corporate finance, and takeovers. American Economic Review, 76(2), 323-329.

Jensen, M.C. \& Meckling, W.H., 1976. Theory of the firm: managerial behavior, agency costs and ownership structure. Journal of Financial Economics, 3(4), 305-360.

Johnson, S. et al., 2000. Tunneling. American Economic Review, 90(2), 22-27.

La Porta, R., Lopez-de-Silanes, F. \& Shleifer, A., 1999. Corporate ownership around the world. Journal of Finance, 54(2), 471-517.

La Porta, R. et al., 1998. Law and finance. Journal of Political Economy, 106(6), 1113-1155.

Laeven, L. \& Levine, R., 2008. Complex ownership structures and corporate valuations. Review of Financial Studies, 21(2), 579-604.

Larcker, D.F. \& Rusticus, T.O., 2010. On the use of instrumental variables in accounting research. Journal of Accounting \& Economics, 49(3), 186-205.

Lins, K.V., 2003. Equity ownership and firm value in emerging markets. Journal of Financial \& Quantitative Analysis, 38(1), 159-184. 
Martynova, M. \& Renneboog, L., 2009. What determines the financing decision in corporate takeovers: Cost of capital, agency problems, or the means of payment? Journal of Corporate Finance, 15(3), 290-315.

Masulis, R.W., Wang, C. \& Xie, F., 2009. Agency problems at dual-class companies. Journal of Finance, 64(4), 1697-1727.

Masulis, R.W., Wang, C. \& Xie, F., 2007. Corporate governance and acquirer returns. Journal of Finance, 62(4), 1851-1889.

Maury, B., 2006. Family ownership and firm performance: Empirical evidence from Western European corporations. Journal of Corporate Finance, 12(2), 321-341.

Maury, B. \& Pajuste, A., 2005. Multiple large shareholders and firm value. Journal of Banking \& Finance, 29(7), 1813-1834.

McConnell, J.J. \& Servaes, H., 1990. Additional evidence on equity ownership and corporate value. Journal of Financial Economics, 27(2), 595-612.

Miller, D., Le Breton-Miller, I. \& Lester, R.H., 2010. Family ownership and acquisition behavior in publicly-traded companies. Strategic Management Journal, 31(2), 201223.

Moeller, S.B. \& Schlingemann, F.P., 2005. Global diversification and bidder gains: A comparison between cross-border and domestic acquisitions. Journal of Banking \& Finance, 29(3), 533-564.

Moeller, S.B., Schlingemann, F.P. \& Stulz, R.M., 2004. Firm size and the gains from acquisitions. Journal of Financial Economics, 73(2), 201-228.

Moeller, S.B., Schlingemann, F.P. \& Stulz, R.M., 2005. Wealth destruction on a massive scale? A study of acquiring-firm returns in the recent merger wave. Journal of Finance, 60(2), 757-782.

Morck, R., Shleifer, A. \& Vishny, R.W., 1990. Do managerial objectives drive bad acquisitions? Journal of Finance, 45(1), 31-48.

Morck, R., Shleifer, A. \& Vishny, R.W., 1988. Management ownership and market valuation: An empirical analysis. Journal of Financial Economics, 20(1/2), 293-315.

Morck, R., Wolfenzon, D. \& Yeung, B., 2005. Corporate governance, economic entrenchment, and growth. Journal of Economic Literature, 43(3), 655-720.

Murphy, A.E., 2005. Corporate ownership in France. The importance of History. In The History of Corporate Governance Around the World. University of Chicago Press: Randall K. Morck ed., pp. 185-222.

Nenova, T., 2003. The value of corporate voting rights and control: A cross-country analysis. Journal of Financial Economics, 68(3), 325-351. 
Perez-Gonzalez, F., 2006. Inherited control and firm performance. American Economic Review, 96(5), 1559-1588.

Riyanto, Y.E. \& Toolsema, L.A., 2008. Tunneling and propping: A justification for pyramidal ownership. Journal of Banking \& Finance, 32(10), 2178-2187.

Roosenboom, P. \& Schramade, W., 2006. The price of power: Valuing the controlling position of owner-managers in French IPO firms. Journal of Corporate Finance, 12(2), 270-295.

Rydqvist, K., 1996. Takeover bids and the relative prices of shares that differ in their voting rights. Journal of Banking \& Finance, 20(8), 1407-1425.

Schlingemann, F.P., Stulz, R.M. \& Walkling, R.A., 2002. Divestitures and the liquidity of the market for corporate assets. Journal of Financial Economics, 64(1), 117-144.

Shleifer, A. \& Vishny, R.W., 1997. A survey of corporate governance. Journal of Finance, 52(2), 737-783.

Shleifer, A. \& Vishny, R.W., 1989. Management entrenchment. Journal of Financial Economics, 25(1), 123-139.

Shleifer, A. \& Vishny, R.W., 2003. Stock market driven acquisitions. Journal of Financial Economics, 70(3), 295-311.

Sraer, D. \& Thesmar, D., 2007. Performance and behavior of family firms: Evidence from the French stock market. Journal of the European Economic Association, 5(4), 709-751.

Stulz, R.M. \& Williamson, R., 2003. Culture, openness, and finance. Journal of Financial Economics, 70(3), 313-349.

Travlos, N.G., 1987. Corporate takeover bids, methods of payment, and bidding firms' stock returns. Journal of Finance, 42(4), 943-963.

Villalonga, B. \& Amit, R., 2009. How are U.S. family firms controlled? Review of Financial Studies, 22(8), 3047-3091.

Winton, A., 1993. Limitation of liability and the ownership structure of the firm. Journal of Finance, 48(2), 487-512.

Wooldridge, J.M., 2002. Econometric analysis of cross section and panel data, The MIT Press.

Zingales, L., 1994. The value of the voting right: a study of the Milan Stock Exchange experience. Review of Financial Studies, 7(1), 125-148. 


\section{Table 1: Sample description}

The sample consists of 660 mergers and acquisitions announced by 196 French companies over the period 2000 $-2009$.

Panel A presents the distribution of the deals across the years and the average (median) deal value reported in the SDC database. Some bidders make more than one acquisition in a given year; the number of bidders is thus lower than the number of acquisitions.

Panel B presents descriptive statistics regarding the characteristics of the bidders (accounting, financial and ownership variables) and the characteristics of the deal.

Variable definitions are in Appendix B.

Panel A: Number of deals, bidders and deal values

\begin{tabular}{ccccc}
\hline Year & $\begin{array}{c}\text { Number of } \\
\text { Deals }\end{array}$ & $\begin{array}{c}\text { Number of } \\
\text { Bidders }\end{array}$ & $\begin{array}{c}\text { Average deal } \\
\text { value }(€ \mathrm{M})\end{array}$ & $\begin{array}{c}\text { Median deal } \\
\text { value }(€ \mathrm{M})\end{array}$ \\
\hline 2000 & 105 & 67 & 1535 & 135 \\
2001 & 72 & 49 & 739 & 183 \\
2002 & 59 & 45 & 362 & 82 \\
2003 & 45 & 38 & 215 & 49 \\
2004 & 62 & 44 & 1010 & 73 \\
2005 & 62 & 45 & 508 & 110 \\
2006 & 71 & 55 & 791 & 140 \\
2007 & 89 & 66 & 652 & 80 \\
2008 & 63 & 50 & 954 & 76 \\
2009 & 32 & 27 & 451 & 227 \\
\hline Total & 60 & 196 & 800 & 105 \\
\hline \hline
\end{tabular}

Panel B: Deals' descriptive statistics

\begin{tabular}{lccc}
\hline \hline & Mean & Median & St. Dev. \\
\hline LOG(ASSETS) & 3.67 & 3.76 & 1.10 \\
TOBIN'S Q & 1.83 & 1.33 & 1.76 \\
DIVER & 0.44 & 0.00 & 0.50 \\
CASH & 0.81 & 1.00 & 0.39 \\
PUBLIC & 0.22 & 0.00 & 0.42 \\
CROSS BORDER & 0.67 & 1.00 & 0.47 \\
INDUSTRY M\&A & 0.06 & 0.03 & 0.07 \\
REL. SIZE & 0.12 & 0.05 & 0.17 \\
S1 UCF & 0.23 & 0.16 & 0.23 \\
WEDGE & 0.08 & 0.05 & 0.11 \\
WEDGE RATIO & 0.79 & 0.88 & 0.26 \\
HIGH WEDGE & 0.50 & 0.50 & 0.50 \\
S2 UVR & 0.05 & 0.00 & 0.08 \\
S234 UVR & 0.06 & 0.00 & 0.10 \\
OTHERS & 0.10 & 0.05 & 0.12 \\
FAMILY & 0.41 & 0.00 & 0.49 \\
F_FAM & 0.19 & 0.00 & 0.39 \\
F_PRO & 0.22 & 0.00 & 0.41 \\
DVR & 0.65 & 1.00 & 0.48 \\
PYRAMID & 0.21 & 0.00 & 0.41 \\
\hline \hline
\end{tabular}




\section{Table 2: Bidder abnormal announcement returns}

The sample consists of 660 mergers and acquisitions announced by 196 French companies over the period 2000 $-2009$.

The cumulative abnormal returns are calculated for the 3-day period around the announcement date (CAR($1,+1)$ ) with a market model whose parameters are estimated over the 200 days period from event day -210 to event day -11 ; I use the SBF250 index return as the market return.

Variable definitions are in Appendix B.

The table provides mean and median values. $* * *, * *, *$ stand for statistical significance based on two-sided tests at the $1 \%, 5 \%$ and $10 \%$ level, respectively. Student t-statistics and Wilcoxon Z-statistics test for the difference in means (medians) between categories.

\begin{tabular}{|c|c|c|c|c|c|c|c|}
\hline & & \multirow{3}{*}{$\begin{array}{c}n= \\
660\end{array}$} & \multirow{3}{*}{$\frac{\% \text { sample }}{100 \%}$} & \multicolumn{4}{|c|}{$\operatorname{CAR}(-1,+1)$} \\
\hline & & & & mean & & median & \\
\hline \multicolumn{2}{|l|}{ WHOLE SAMPLE } & & & $0.69 \%$ & $* * *$ & $0.28 \%$ & $* * *$ \\
\hline \multirow[t]{3}{*}{ DIVER } & 0 & 370 & $56 \%$ & $1.11 \%$ & $* * *$ & $0.65 \%$ & *** \\
\hline & 1 & 290 & $44 \%$ & $0.15 \%$ & & $-0.02 \%$ & \\
\hline & $\mathrm{t} / \mathrm{z}-\mathrm{test}$ & & & 2.18 & $* *$ & 1.89 & $*$ \\
\hline \multirow[t]{3}{*}{$\mathrm{CASH}$} & 0 & 124 & $19 \%$ & $0.17 \%$ & & $-0.15 \%$ & \\
\hline & 1 & 536 & $81 \%$ & $0.81 \%$ & $* * *$ & $0.33 \%$ & $* * *$ \\
\hline & $\mathrm{t} / \mathrm{z}-$ test & & & -1.13 & & -1.43 & \\
\hline \multirow[t]{3}{*}{ PUBLIC } & 0 & 513 & $78 \%$ & $1.05 \%$ & $* * *$ & $0.38 \%$ & $* * *$ \\
\hline & 1 & 147 & $22 \%$ & $-0.55 \%$ & & $-0.01 \%$ & \\
\hline & $\mathrm{t} / \mathrm{z}-$ test & & & 3.04 & $* * *$ & 1.99 & $* *$ \\
\hline \multirow[t]{3}{*}{ CROSS-BORDER } & 0 & 216 & $33 \%$ & $1.17 \%$ & $* * *$ & $0.47 \%$ & $* * *$ \\
\hline & 1 & 444 & $67 \%$ & $0.46 \%$ & $*$ & $0.13 \%$ & \\
\hline & $\mathrm{t} / \mathrm{z}-$ test & & & 1.51 & & 1.49 & \\
\hline \multirow{3}{*}{ HIGH WEDGE } & 0 & 330 & $50 \%$ & $1.01 \%$ & $* * *$ & $0.44 \%$ & $* * *$ \\
\hline & 1 & 330 & $50 \%$ & $0.37 \%$ & & $0.15 \%$ & \\
\hline & $\mathrm{t} / \mathrm{z}-\mathrm{test}$ & & & 1.45 & & 1.29 & \\
\hline \multirow[t]{3}{*}{ DVR } & 0 & 228 & $35 \%$ & $1.17 \%$ & $* * *$ & $0.47 \%$ & \\
\hline & 1 & 432 & $65 \%$ & $0.46 \%$ & $*$ & $0.13 \%$ & $* *$ \\
\hline & $\mathrm{t} / \mathrm{z}-$ test & & & 1.21 & & 0.04 & \\
\hline \multirow[t]{3}{*}{ PYRAMID } & 0 & 519 & $79 \%$ & $0.66 \%$ & $* * *$ & $0.19 \%$ & $* *$ \\
\hline & 1 & 141 & $21 \%$ & $0.82 \%$ & $*$ & $0.35 \%$ & \\
\hline & $\mathrm{t} / \mathrm{z}-\mathrm{test}$ & & & 1.21 & & 0.04 & \\
\hline \multirow[t]{3}{*}{ FAMILY } & 0 & 389 & $59 \%$ & $0.53 \%$ & $*$ & $0.08 \%$ & \\
\hline & 1 & 271 & $41 \%$ & $0.92 \%$ & $* * *$ & $0.55 \%$ & $* * *$ \\
\hline & $\mathrm{t} / \mathrm{z}-\mathrm{test}$ & & & -0.88 & & -1.38 & \\
\hline
\end{tabular}


Table 3: Announcement abnormal returns and ownership characteristics

The sample consists of 660 mergers and acquisitions announced by 196 French companies over the period 2000 -2009. The dependant variable is the 3-day cumulative abnormal return $(\mathrm{CAR}(-1,+1))$. Variable definitions are in Appendix B. Year and sector (1-digit SIC code) dummies are included in the regressions but are not reported. In parentheses are t-statistics based on standard errors adjusted for heteroskedasticity (White, 1980) and acquirer clustering. Asterisks denote statistical significance at the 1\% (***), 5\% (**), or 10\% (*) level, respectively.

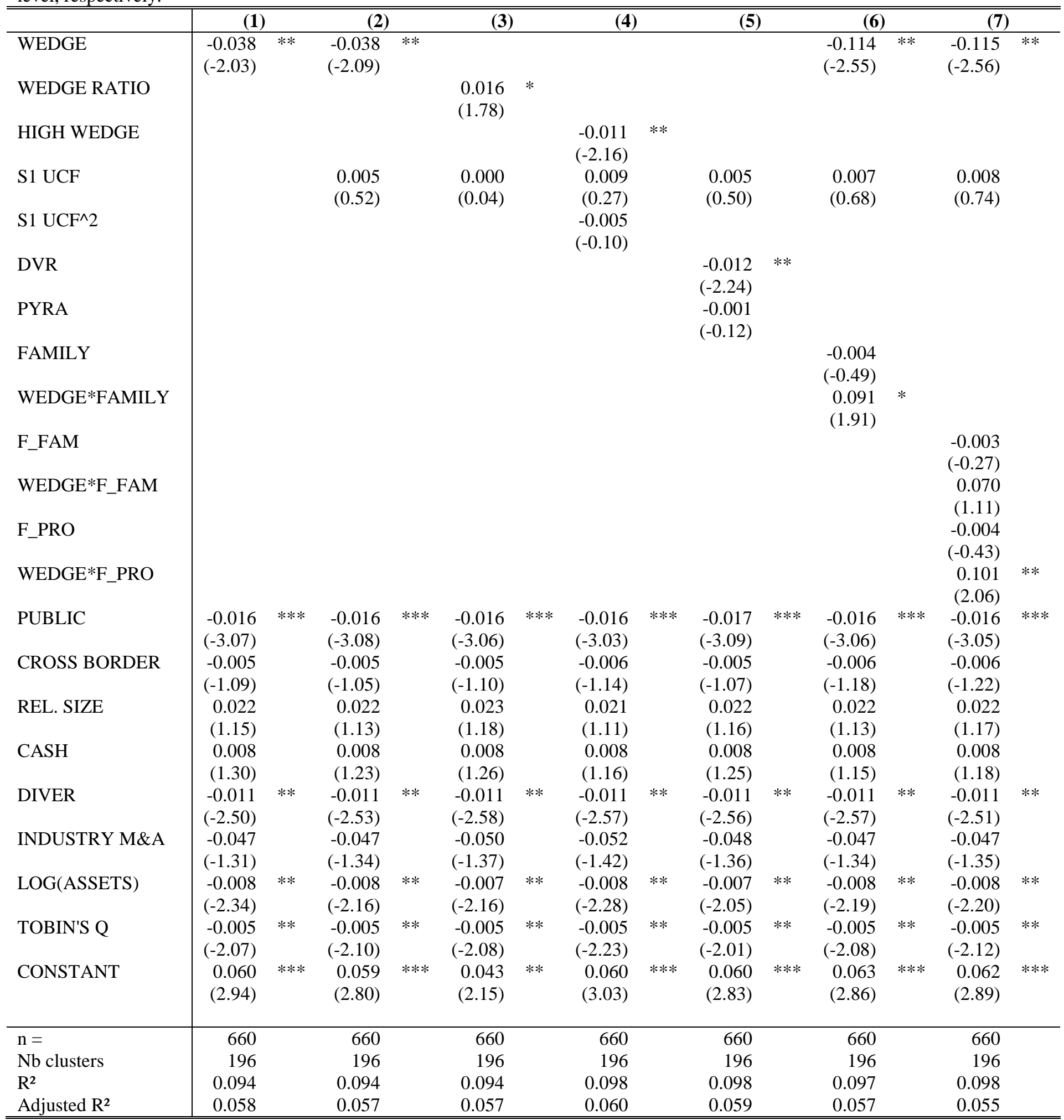




\section{Table 4: Impact of other blockholders on announcement abnormal returns}

The sample consists of 660 mergers and acquisitions announced by 196 French companies over the period 2000-2009. The dependant variable is the 3-day cumulative abnormal return $(\mathrm{CAR}(-1,+1))$. Variable definitions are in Appendix B. Year and sector (1-digit SIC code) dummies are included in the regressions but are not reported. In parentheses are t-statistics based on standard errors adjusted for heteroskedasticity (White, 1980) and acquirer clustering. Asterisks denote statistical significance at the $1 \%(* * *), 5 \%(* *)$, or $10 \%(*)$ level, respectively.

\begin{tabular}{|c|c|c|c|c|c|c|c|c|c|c|c|c|}
\hline \multirow[b]{2}{*}{ WEDGE } & \multicolumn{2}{|c|}{ (1) } & \multicolumn{2}{|l|}{ (2) } & \multicolumn{2}{|c|}{ (3) } & \multicolumn{2}{|c|}{ (4) } & \multicolumn{2}{|c|}{ (5) } & \multicolumn{2}{|c|}{$(6)$} \\
\hline & $\begin{array}{l}-0.042 \\
(-2.31)\end{array}$ & $* *$ & $\begin{array}{l}-0.043 \\
(-2.33)\end{array}$ & $* *$ & $\begin{array}{l}-0.044 \\
(-2.40)\end{array}$ & $* *$ & $\begin{array}{l}-0.039 \\
(-2.14)\end{array}$ & $* *$ & $\begin{array}{l}-0.043 \\
(-2.33)\end{array}$ & $* *$ & $\begin{array}{l}-0.044 \\
(-2.38)\end{array}$ & $* *$ \\
\hline S1 UCF & $\begin{array}{r}0.006 \\
(0.61)\end{array}$ & & $\begin{array}{l}0.006 \\
(0.56)\end{array}$ & & $\begin{array}{c}0.006 \\
(0.55)\end{array}$ & & $\begin{array}{l}0.006 \\
(0.56)\end{array}$ & & $\begin{array}{l}0.005 \\
(0.49)\end{array}$ & & $\begin{array}{l}0.005 \\
(0.49)\end{array}$ & \\
\hline S2 UVR & $\begin{array}{l}-0.044 \\
(-1.60)\end{array}$ & & & & & & & & & & & \\
\hline S234 UVR & & & $\begin{array}{l}-0.042 \\
(-1.90)\end{array}$ & $*$ & & & & & & & & \\
\hline OTHERS & & & & & $\begin{array}{l}-0.045 \\
(-2.27)\end{array}$ & $* *$ & & & & & & \\
\hline AGREEMENT & & & & & & & $\begin{array}{r}-0.003 \\
(-0.52)\end{array}$ & & $\begin{array}{l}-0.001 \\
(-0.06)\end{array}$ & & $\begin{array}{l}-0.001 \\
(-0.06)\end{array}$ & \\
\hline S234 AGREEMENT & & & & & & & & & $\begin{array}{l}-0.025 \\
(-0.72)\end{array}$ & & & \\
\hline S234 NoAGREEMENT & & & & & & & & & $\begin{array}{l}-0.069 \\
(-1.87)\end{array}$ & $*$ & & \\
\hline OTHERS AGREEMENT & & & & & & & & & & & $\begin{array}{l}-0.021 \\
(-0.48)\end{array}$ & \\
\hline OTHERS NoAGREEMENT & & & & & & & & & & & $\begin{array}{l}-0.065 \\
(-2.41)\end{array}$ & $* *$ \\
\hline PUBLIC & $\begin{array}{l}-0.016 \\
(-2.92)\end{array}$ & $* * *$ & $\begin{array}{l}-0.016 \\
(-2.96)\end{array}$ & $* * *$ & $\begin{array}{l}-0.016 \\
(-2.98)\end{array}$ & $* * *$ & $\begin{array}{l}-0.016 \\
(-3.01)\end{array}$ & $* * *$ & $\begin{array}{l}-0.016 \\
(-2.98)\end{array}$ & $* * *$ & $\begin{array}{l}-0.016 \\
(-3.01)\end{array}$ & $* * *$ \\
\hline CROSS BORDER & $\begin{array}{l}-0.005 \\
(-1.08)\end{array}$ & & $\begin{array}{l}-0.005 \\
(-1.10)\end{array}$ & & $\begin{array}{l}-0.005 \\
(-1.05)\end{array}$ & & $\begin{array}{l}-0.005 \\
(-1.06)\end{array}$ & & $\begin{array}{l}-0.005 \\
(-1.02)\end{array}$ & & $\begin{array}{l}-0.005 \\
(-0.99)\end{array}$ & \\
\hline REL. SIZE & $\begin{array}{l}0.024 \\
(1.28)\end{array}$ & & $\begin{array}{l}0.025 \\
(1.29)\end{array}$ & & $\begin{array}{l}0.025 \\
(1.33)\end{array}$ & & $\begin{array}{l}0.022 \\
(1.17)\end{array}$ & & $\begin{array}{l}0.024 \\
(1.27)\end{array}$ & & $\begin{array}{l}0.025 \\
(1.29)\end{array}$ & \\
\hline $\mathrm{CASH}$ & $\begin{array}{l}0.009 \\
(1.34)\end{array}$ & & $\begin{array}{l}0.009 \\
(1.32)\end{array}$ & & $\begin{array}{l}0.009 \\
(1.32)\end{array}$ & & $\begin{array}{c}0.008 \\
(1.23)\end{array}$ & & $\begin{array}{l}0.008 \\
(1.30)\end{array}$ & & $\begin{array}{l}0.008 \\
(1.29)\end{array}$ & \\
\hline DIVER & $\begin{array}{l}-0.011 \\
(-2.56)\end{array}$ & $* *$ & $\begin{array}{l}-0.011 \\
(-2.55)\end{array}$ & $* *$ & $\begin{array}{l}-0.011 \\
(-2.59)\end{array}$ & $* *$ & $\begin{array}{l}-0.010 \\
(-2.48)\end{array}$ & $* *$ & $\begin{array}{l}-0.011 \\
(-2.56)\end{array}$ & $* *$ & $\begin{array}{l}-0.011 \\
(-2.65)\end{array}$ & $* * *$ \\
\hline INDUSTRY M\&A & $\begin{array}{l}-0.049 \\
(-1.38)\end{array}$ & & $\begin{array}{l}-0.049 \\
(-1.38)\end{array}$ & & $\begin{array}{l}-0.051 \\
(-1.43)\end{array}$ & & $\begin{array}{r}-0.048 \\
(-1.34)\end{array}$ & & $\begin{array}{l}-0.049 \\
(-1.39)\end{array}$ & & $\begin{array}{l}-0.052 \\
(-1.45)\end{array}$ & \\
\hline LOG(ASSETS) & $\begin{array}{l}-0.008 \\
(-2.32)\end{array}$ & $* *$ & $\begin{array}{l}-0.009 \\
(-2.41)\end{array}$ & $* *$ & $\begin{array}{r}-0.009 \\
(-2.53)\end{array}$ & $* *$ & $\begin{array}{l}-0.008 \\
(-2.17)\end{array}$ & $* *$ & $\begin{array}{l}-0.009 \\
(-2.54)\end{array}$ & $* *$ & $\begin{array}{r}-0.010 \\
(-2.67)\end{array}$ & $* * *$ \\
\hline TOBIN'S Q & $\begin{array}{l}-0.005 \\
(-2.01)\end{array}$ & $* *$ & $\begin{array}{l}-0.005 \\
(-2.02)\end{array}$ & $* *$ & $\begin{array}{l}-0.005 \\
(-2.06)\end{array}$ & $* *$ & $\begin{array}{l}-0.005 \\
(-2.05)\end{array}$ & $* *$ & $\begin{array}{l}-0.005 \\
(-2.08)\end{array}$ & $* *$ & $\begin{array}{l}-0.005 \\
(-2.13)\end{array}$ & $* *$ \\
\hline CONSTANT & $\begin{array}{l}0.063 \\
(2.91)\end{array}$ & $* * *$ & $\begin{array}{l}0.065 \\
(2.98)\end{array}$ & $* * *$ & $\begin{array}{r}0.069 \\
(3.06)\end{array}$ & $* * *$ & $\begin{array}{l}0.059 \\
(2.79)\end{array}$ & $* * *$ & $\begin{array}{r}0.068 \\
(3.07)\end{array}$ & $* * *$ & $\begin{array}{r}0.073 \\
(3.18)\end{array}$ & $* * *$ \\
\hline $\begin{array}{l}\mathrm{n}= \\
\mathrm{Nb} \text { Clusters } \\
\mathrm{R}^{2} \\
\text { Adjusted } \mathrm{R}^{2}\end{array}$ & $\begin{array}{r}660 \\
196 \\
0.098 \\
0.059\end{array}$ & & $\begin{array}{r}660 \\
196 \\
0.099 \\
0.061\end{array}$ & & $\begin{array}{r}660 \\
196 \\
0.102 \\
0.064\end{array}$ & & $\begin{array}{r}660 \\
196 \\
0.095 \\
0.056\end{array}$ & & $\begin{array}{r}660 \\
196 \\
0.101 \\
0.059\end{array}$ & & $\begin{array}{r}660 \\
196 \\
0.104 \\
0.063\end{array}$ & \\
\hline
\end{tabular}


Table 5: Bidding vs. Non bidding firms

Means, medians, standard deviations and tests of differences in means and medians between bidding and non bidding firms. Student t-statistics and Wilcoxon Z-statistics test for the differences in means and medians between the two categories.

Bidding firms are defined as those announcing a corporate acquisition in the following year. Variable definitions are in Appendix B, except ASSETS which refers to the book value of assets in euro millions and MARKET CAP (market value of equity in $€$ millions).

The sample comprises 3,063firm-year observations from 401 SBF 250 firms listed in France over the period 1999 through 2008 . Asterisks denote statistical significance at the $1 \%(* * *), 5 \%(* *)$, or $10 \%(*)$ level, respectively.

\begin{tabular}{|c|c|c|c|c|c|c|c|c|c|c|c|}
\hline & \multirow{2}{*}{\multicolumn{3}{|c|}{$\begin{array}{c}\text { Whole sample } \\
n=3,063\end{array}$}} & \multirow{2}{*}{\multicolumn{2}{|c|}{$\begin{array}{c}\text { Non bidding } \\
\text { firms }[\mathrm{A}] \\
n=2,566\end{array}$}} & \multirow{2}{*}{\multicolumn{2}{|c|}{$\begin{array}{c}\text { Bidding firms } \\
{[\mathrm{B}]} \\
\mathrm{n}=497\end{array}$}} & \multicolumn{4}{|c|}{$\begin{array}{l}\text { Test for differences } \\
([\mathbf{A}]-[\mathbf{B}]) \text { in }\end{array}$} \\
\hline & & & & & & & & Mear & & Medic & \\
\hline & Mean & Median & St. Dev & Mean & Median & Mean & Median & $\mathrm{t}$-test & & $z$-test & \\
\hline ASSETS GROWTH & 0.21 & 0.07 & 0.66 & 0.18 & 0.07 & 0.36 & 0.10 & -5.42 & $* * *$ & -4.36 & $* * *$ \\
\hline ASSETS & 17636 & 605 & 104482 & 10735 & 517 & 53266 & 3270 & -8.40 & $* * *$ & -12.76 & $* * *$ \\
\hline MARKET CAP & 3874 & 426 & 11752 & 2699 & 341 & 9941 & 2394 & -12.91 & $* * *$ & -15.48 & $* * *$ \\
\hline LOG(ASSETS) & 2.95 & 2.78 & 0.93 & 2.85 & 2.71 & 3.49 & 3.51 & -14.47 & $* * *$ & -12.76 & $* * *$ \\
\hline LEVERAGE & 0.24 & 0.23 & 0.17 & 0.24 & 0.23 & 0.24 & 0.23 & 0.46 & & -0.17 & \\
\hline PPE/ASS & 0.21 & 0.14 & 0.21 & 0.20 & 0.14 & 0.23 & 0.13 & -2.18 & $* *$ & -0.36 & \\
\hline TOBIN'S Q & 1.70 & 1.30 & 1.50 & 1.68 & 1.28 & 1.80 & 1.35 & -1.55 & & -3.54 & $* * *$ \\
\hline LISTING USA & 0.07 & 0.00 & 0.25 & 0.05 & 0.00 & 0.17 & 0.00 & -9.87 & $* * *$ & -9.72 & $* * *$ \\
\hline HIGH TECH & 0.15 & 0.00 & 0.36 & 0.15 & 0.00 & 0.19 & 0.00 & -2.12 & $* *$ & -2.12 & $* *$ \\
\hline INDUSTRY M\&A & 0.05 & 0.03 & 0.07 & 0.05 & 0.03 & 0.06 & 0.03 & -2.60 & $* * *$ & -2.06 & $* *$ \\
\hline S1 UCF & 0.36 & 0.33 & 0.25 & 0.38 & 0.35 & 0.25 & 0.20 & 10.37 & $* * *$ & 10.54 & $* * *$ \\
\hline WEDGE & 0.10 & 0.08 & 0.11 & 0.10 & 0.08 & 0.08 & 0.05 & 3.88 & $* * *$ & 5.59 & $* * *$ \\
\hline WEDGE RATIO & 0.78 & 0.83 & 0.23 & 0.78 & 0.83 & 0.79 & 0.88 & -0.50 & & -2.39 & $* *$ \\
\hline HIGH WEDGE & 0.50 & 0.00 & 0.50 & 0.51 & 1.00 & 0.46 & 0.00 & 2.10 & $* *$ & 2.10 & $* *$ \\
\hline S2 UVR & 0.06 & 0.00 & 0.10 & 0.07 & 0.00 & 0.06 & 0.00 & 1.79 & $*$ & 1.48 & \\
\hline S234 UVR & 0.08 & 0.00 & 0.12 & 0.08 & 0.00 & 0.07 & 0.00 & 1.84 & $*$ & 1.42 & \\
\hline OTHERS & 0.12 & 0.06 & 0.14 & 0.12 & 0.07 & 0.11 & 0.06 & 1.71 & $*$ & 1.49 & \\
\hline FAMILY & 0.62 & 1.00 & 0.49 & 0.65 & 1.00 & 0.46 & 0.00 & 8.18 & $* * *$ & 8.09 & $* * *$ \\
\hline DVR & 0.69 & 1.00 & 0.46 & 0.69 & 1.00 & 0.65 & 1.00 & 2.18 & $* *$ & 2.18 & $* *$ \\
\hline PYRAMID & 0.26 & 0.00 & 0.44 & 0.26 & 0.00 & 0.22 & 0.00 & 2.03 & $* *$ & 2.03 & $* *$ \\
\hline
\end{tabular}




\section{Table 6: Determinants of the bidding likelihood}

The sample comprises 3,063 firm-year observations from 401 SBF 250 firms listed in France over the period 1999 to 2008. Regressions (1), (2), (3), (4), and (6) are Probit regressions whose dependant variable is equal to one whether the firm announces an acquisition in the following year. In column (5) are the results of a Tobit regression in which the dependant variable is equal to the ratio (total value of the deals announced in year $t+1 /$ market capitalization at the end of year $t$ ). In regression (6), firms classified as belonging to the banking or insurance sectors are excluded.

Variable definitions are in Appendix B. Year and sector (1-digit SIC code) dummies are included in the regressions but are not reported.

In parentheses are z-statistics based on standard errors adjusted for heteroskedasticity (Huber/White). In regression (5), the tstatistics are in parentheses and are based on standard errors adjusted for heteroskedasticity (White, 1980).

Asterisks denote statistical significance at the $1 \%(* * *), 5 \%(* *)$, or $10 \%(*)$ level, respectively.

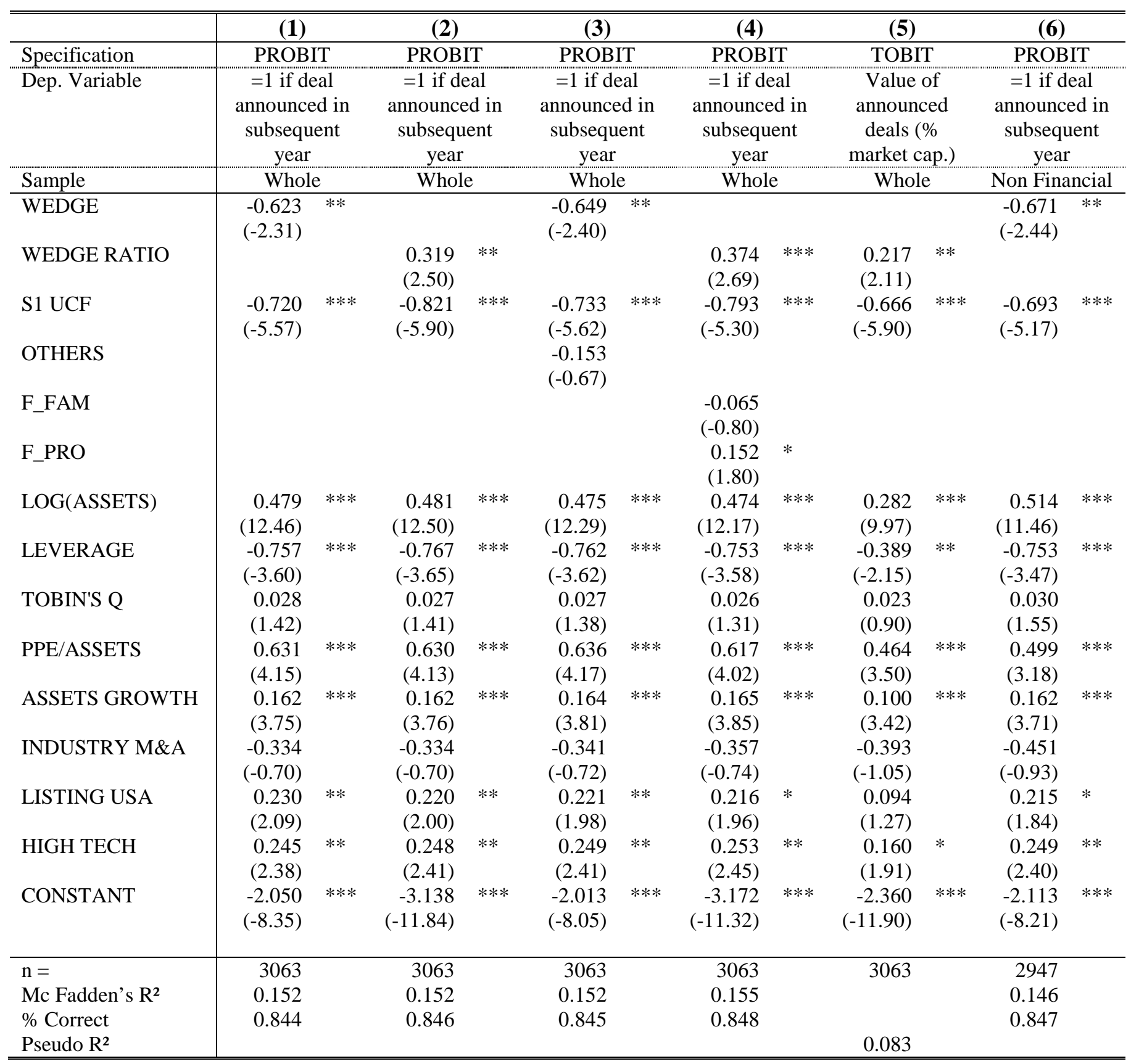




\section{Table 7: Robustness checks}

In regressions (4), (5), and (6) I use the sample of 660 mergers and acquisitions announced by 196 French companies over the period 2000-2009. In regression (1), the focus is on completed deals (the deals that are announced but not completed are excluded). In regression (2), firms which do not have at least one controlling shareholder holding at least $10 \%$ of the voting rights are excluded. In regression (3), I exclude all the deals made by companies which announced another deal in the 210 preceding days. In regression (7), bidders classified as belonging to the financial sector (banks and insurance companies) are excluded.

In regression (1), (2), (3), (6) and (7), the dependant variable is the 3-day cumulative abnormal return (CAR(-1,+1)) while I use CAR(-2,+2) in regression (4). All regressions are OLS regressions except regression (5) which is a LOGIT specification. In this LOGIT model, the dependant variable takes the value of one whether the cumulative abnormal return computed over a 5-day period (CAR $(-2,+2))$ is negative. Variable definitions are in Appendix B. Year and sector (1-digit SIC code) dummies are included in the regressions but are not reported.

In regression (6) and (7), the inverse Mills' ratio (INV MILLS) computed with Probit estimates of Table 6 (from regressions (2) and (6) respectively) are included.

In parentheses are t-statistics based on standard errors adjusted for heteroskedasticity (White, 1980) and acquirer clustering. In regression (5), the z-stats are in parentheses and are based on Huber/White heteroskedasticity consistent standard errors.

Asterisks denote statistical significance at the $1 \%(* * *), 5 \%(* *)$, or $10 \%(*)$ level, respectively.

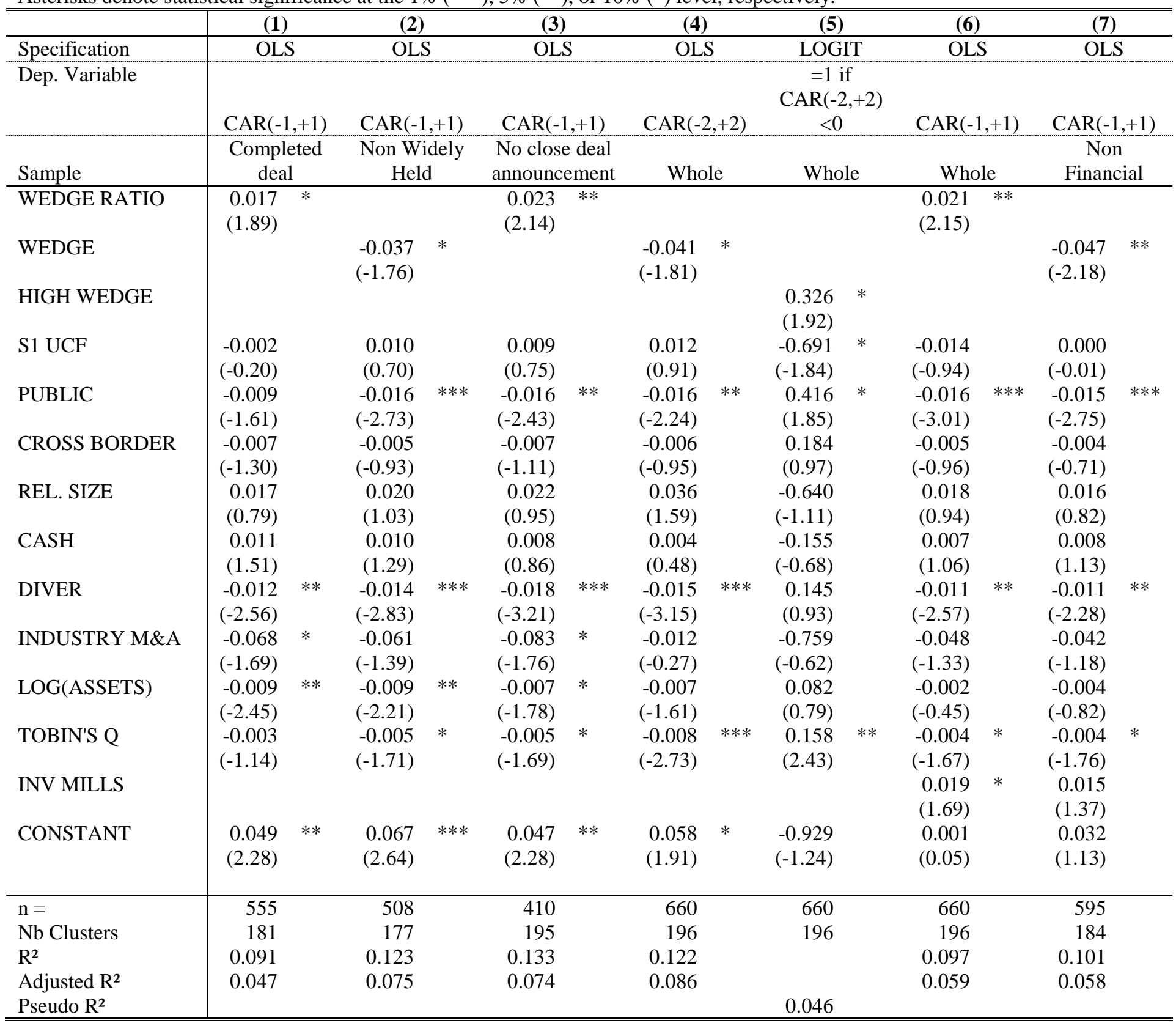


Table 8: Endogeneity issues

The sample consists of 660 mergers and acquisitions announced by 196 French companies over the period $2000-2009$. This table presents two-stage least squares regressions. In regression (3) and (4), the sample is restricted to the 555 acquisitions that are classified as "completed" in the SDC database. In regression (5), firms which do not have at least one controlling shareholder holding at least $10 \%$ of the voting rights are excluded. The variable treated as endogenous is WEDGE (the difference between voting and cash-flow rights of the largest shareholder), the instruments are YEARS IPO (number of years since first appearance of the company in Datastream) and PCT SALES (ratio of firm's sales to the sales of all firms in the same geographical area). For the first stage, I only report the coefficient estimates for the excluded instruments. In regression (1) and (3), the dependant variable is the 3-day cumulative abnormal return $(\mathbf{C A R}(-\mathbf{1},+\mathbf{1}))$ while regressions (2) and (4) are estimated with CAR $(-2,+2)$ as dependant variable. In regression (5), the dependant variable is a dummy variable which takes a value of one when CAR $(-2,+2)$ is negative.

Variable definitions are in Appendix B. Year and sector dummies (based on the 1-digit SIC code) are included in the regressions but are not reported. In parentheses are t-statistics based on standard errors adjusted for heteroskedasticity. Asterisks denote statistical significance at the $1 \%(* * *), 5 \%(* *)$, or $10 \%(*)$ level, respectively.

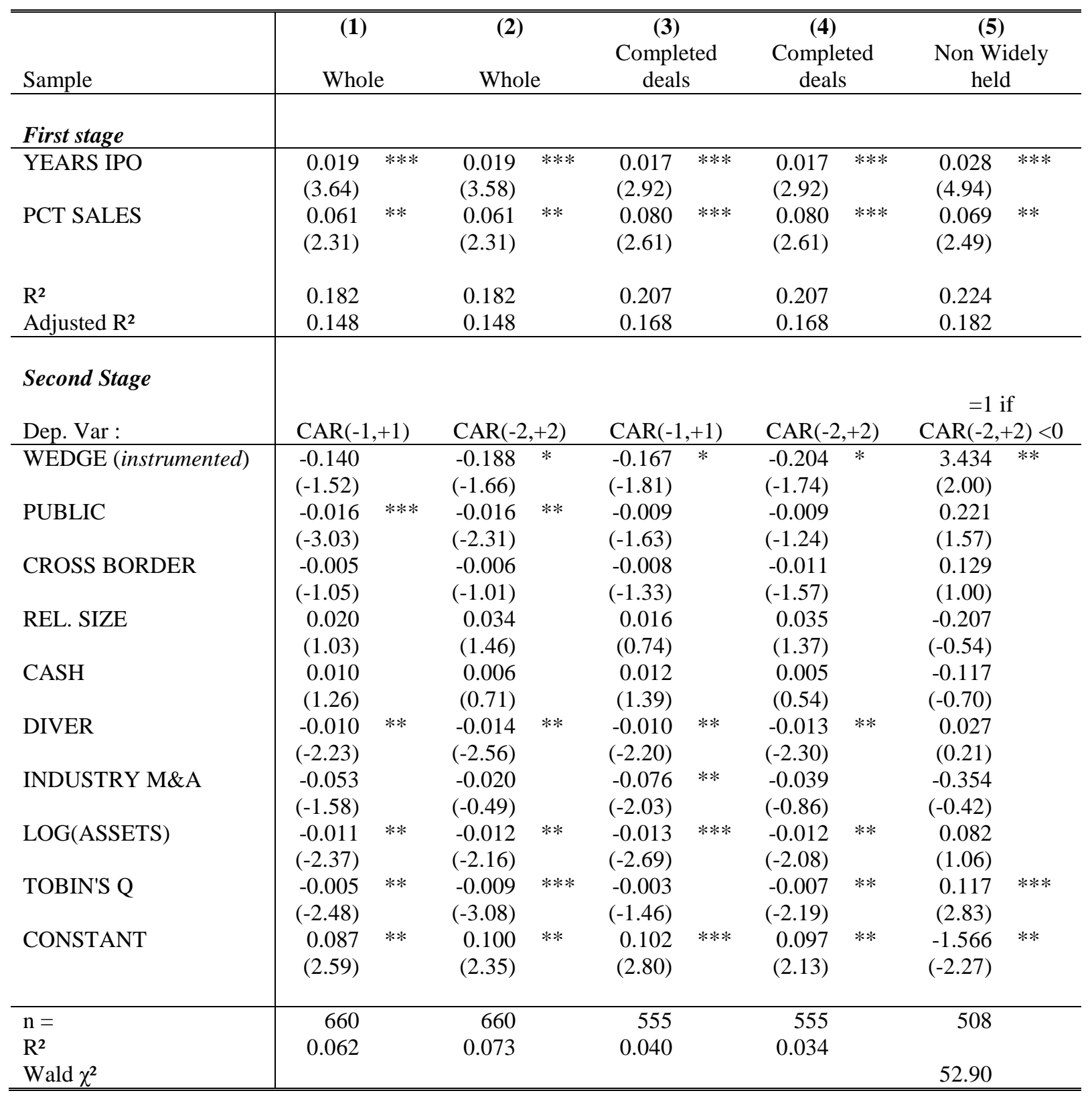

